Supporting Information for

\title{
Bifunctional carbenium dications as metal-free catalysts for the reduction of oxygen
}

Mohammadjavad Karimi, Rosmita Borthakur, Christopher L. Dorsey, Chang-Hong Chen, Sébastien Lajeune and François P. Gabbaï*

Department of Chemistry, Texas A\&M University, College Station, Texas 77843, United States

\section{Table of Contents}

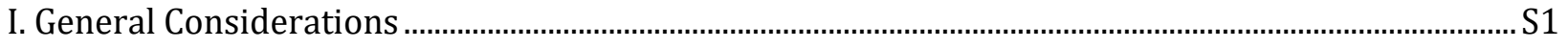

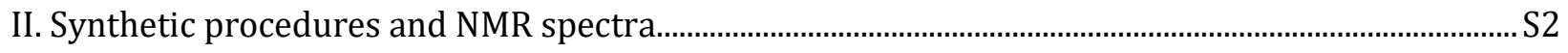

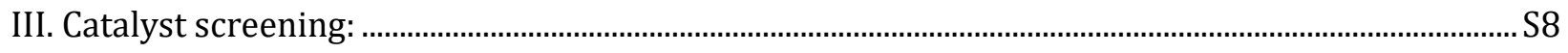

IV. Comparison of rates in the presence and absence of $\mathrm{H}_{2} \mathrm{O}_{2}$ and buffer.................................................. 8

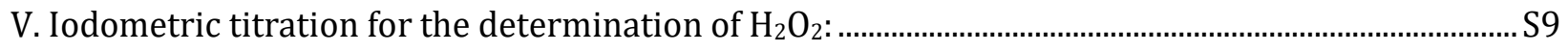

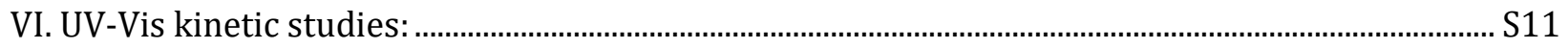

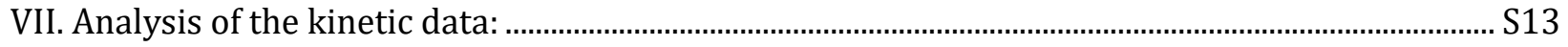

VIII. In situ generation of the bridged peroxides and protonolysis.......................................................... S14

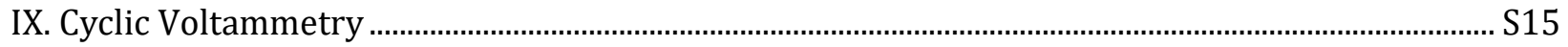

X. Open Circuit Potential measurement and overpotential analysis............................................................ S18

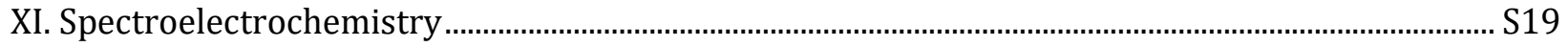

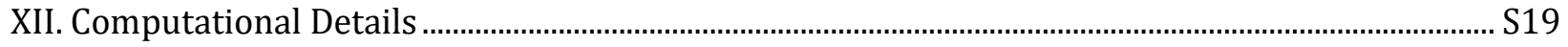

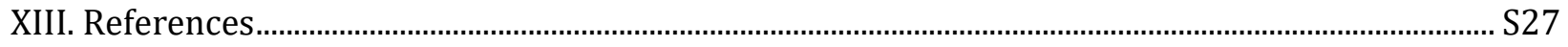

\section{General Considerations}

All manipulations were carried out under an atmosphere of $\mathrm{N}_{2}$ using standard Schlenk and glovebox techniques. Diethylether and hexanes were dried by distillation over $\mathrm{Na} / \mathrm{K}$, prior to use. All commercially available reagents were used as received. Column chromatography was performed using Merck 60 silica gel (100-200 mesh). ${ }^{1} \mathrm{H}$ and ${ }^{13} \mathrm{C}$ spectra were recorded on a Bruker Avance 500 FT NMR (499.42 MHz for ${ }^{1} \mathrm{H}, 469.84 \mathrm{MHz}$ for ${ }^{19} \mathrm{~F}, 125.58 \mathrm{MHz}$ for ${ }^{13} \mathrm{C}$ ) spectrometer. Chemical shifts are given in parts per million (ppm) with respect to the solvent. UV-Vis experiments were conducted using a Shimadzu 2502PC UV-Vis spectrophotometer and the absorption values were recorded against a solvent reference. Qualitative CV experiments and spectroelectrochemical 
studies were performed with a CH Instruments 610A potentiostat, and all quantitative measurements were performed using a Gamry Interface 1000 potentiostat. The Open Circuit Potential (OCP) measurement was conducted on a Gamry Interface 1000 potentiostat. Spectroelectrochemical studies were conducted using a Hewlett-Packard 8453 spectrophotometer employing a dual tungsten/deuterium lamp source. An optically transparent honeycomb Pt electrode $(b=1.7 \mathrm{~mm})$ was employed in a capillary slit cell. Elemental analyses were performed at Atlantic Microlab (Norcross, GA).

\section{Synthetic procedures and NMR spectra}

General remarks:

Compounds $[1]\left[\mathrm{BF}_{4}\right]^{1},[2]\left[\mathrm{BF}_{4}\right]_{2}^{2}$, 4,5-dilithio-9,9-dimethylxanthene ${ }^{3}$ and 1,8-dibromobiphenylene 4 were synthesized according to previously published procedures.

\section{Synthesis of the 1,8-biphenylene derivatives}

\section{Synthesis of $3-(\mathrm{OH})_{2}$ :}

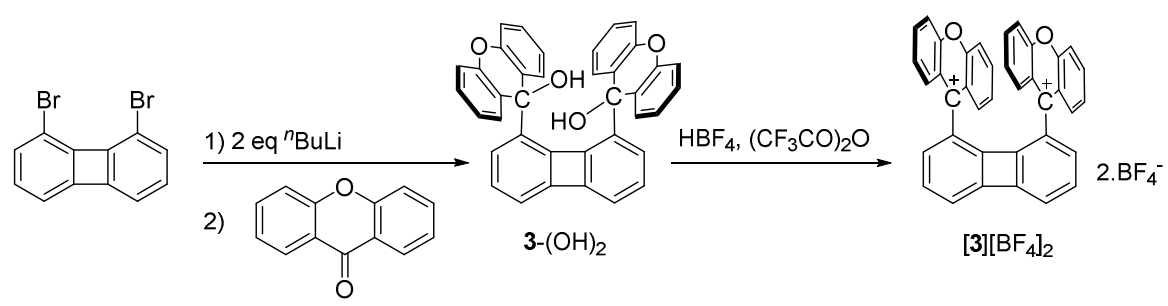

${ }^{n} \operatorname{BuLi}(2.65 \mathrm{M}, 1.1 \mathrm{~mL}, 2.92 \mathrm{mmol}$ ) was slowly added to a solution of 1,8-dibromobiphenylene (370 $\mathrm{mg}, 1.2 \mathrm{mmol}$ ) in dry $\mathrm{Et}_{2} \mathrm{O}(5 \mathrm{~mL})$ under $\mathrm{N}_{2}$ at room temperature. After 30 min of stirring, a solution of xanthone ( $540 \mathrm{mg}, 2.8 \mathrm{mmol})$ in $\mathrm{Et}_{2} \mathrm{O}(5 \mathrm{~mL})$ was slowly transferred into the reaction flask using a cannula. The reaction mixture was stirred for an additional $12 \mathrm{~h}$ at room temperature. The solution was then treated with saturated $\mathrm{NH}_{4} \mathrm{Cl}_{(\mathrm{aq})}(1 \mathrm{~mL})$ and the solvent was removed under vacuum. The crude solid was dissolved in $\mathrm{CH}_{2} \mathrm{Cl}_{2}(5 \mathrm{~mL})$. The resulting solution was filtered and brought to dryness under vacuum. The off-white solid was washed with $\mathrm{Et}_{2} \mathrm{O}(15 \mathrm{~mL})$ twice and dried under vacuum to afford $3-(\mathrm{OH})_{2}$ as a white powder (529 mg, $81 \%$ yield). ${ }^{1} \mathrm{H}$ NMR (499.55 $\mathrm{MHz}, 25{ }^{\circ} \mathrm{C}, \mathrm{CDCl}_{3}$ ): $\delta 7.69\left(\mathrm{dd}, 4 \mathrm{H},{ }^{3} \mathrm{~J}_{\mathrm{H}-\mathrm{H}}=7.8 \mathrm{~Hz},{ }^{4} \mathrm{~J}_{\mathrm{H}-\mathrm{H}}=1.5 \mathrm{~Hz}\right.$ ), 7.30 (pseudo t, $4 \mathrm{H},{ }^{3} \mathrm{~J}_{\mathrm{H}-\mathrm{H}}=6.3 \mathrm{~Hz}$ ), $7.16\left(\mathrm{dd}, 4 \mathrm{H},{ }^{3} \mathrm{~J}_{\mathrm{H}-\mathrm{H}}=7.3 \mathrm{~Hz},{ }^{4} \mathrm{~J}_{\mathrm{H}-\mathrm{H}}=1.0 \mathrm{~Hz}\right.$ ), 7.11 (pseudo t, $4 \mathrm{H},{ }^{3} \mathrm{~J}_{\mathrm{H}-\mathrm{H}}=7.3 \mathrm{~Hz}$ ), 6.63-6.58 (m, $4 \mathrm{H}$, biphenylene- $\mathrm{CH}$ ), $6.13\left(\mathrm{dd}, 2 \mathrm{H},{ }^{3} \mathrm{~J}_{\mathrm{H}-\mathrm{H}}=8.3 \mathrm{~Hz},{ }^{4} \mathrm{~J}_{\mathrm{H}-\mathrm{H}}=1.5 \mathrm{~Hz}\right.$, biphenylene- $\mathrm{CH}$ ), $5.67(\mathrm{~s}, 2 \mathrm{H},-\mathrm{OH}) \mathrm{ppm}$. ${ }^{13} \mathrm{C}$ NMR $\left(125.62 \mathrm{MHz}, 25{ }^{\circ} \mathrm{C}, \mathrm{CDCl}_{3}\right): \delta 150.21,149.79,147.70,140.69,131.28,130.19,129.28$, $128.15,125.56,123.43,116.47,114.31,71.78 \mathrm{ppm}$.

Synthesis of [3][BF $]_{2}$ : A suspension of $3-(\mathrm{OH})_{2}(150 \mathrm{mg}, 0.27 \mathrm{mmol}$ ) in TFA anhydride (4.5 ml) was treated with $48 \% \mathrm{HBF}_{4(\mathrm{aq})}(0.25 \mathrm{ml}, 1.36 \mathrm{mmol})$ at room temperature. The reaction mixture was stirred for $2 \mathrm{~h}$ and $\mathrm{Et}_{2} \mathrm{O}(10 \mathrm{ml})$ was added to the mixture in one portion. The resulting suspension was then filtered and the dark green powder was further washed with $\mathrm{Et}_{2} \mathrm{O}(10 \mathrm{ml})$ twice to afford the air- and moisture-stable salt [3][BF $]_{2}\left(148 \mathrm{mg}, 80 \%\right.$ yield). ${ }^{1} \mathrm{H}$ NMR (499.55 $\mathrm{MHz}, 25{ }^{\circ} \mathrm{C}, \mathrm{CD}_{3} \mathrm{CN}$ ): $\delta 8.21$ (pseudo t, $4 \mathrm{H},{ }^{3} \mathrm{~J}_{\mathrm{H}-\mathrm{H}}=7.5 \mathrm{~Hz}$ ), $8.12\left(\mathrm{~d}, 4 \mathrm{H},{ }^{3} \mathrm{~J}_{\mathrm{H}-\mathrm{H}}=8.4 \mathrm{~Hz}\right) 8.09\left(\mathrm{~d}, 4 \mathrm{H},{ }^{3} \mathrm{~J}_{\mathrm{H}-\mathrm{H}}\right.$ $=8.6 \mathrm{~Hz}), 7.58\left(\mathrm{t}, 4 \mathrm{H},{ }^{3} \mathrm{~J}_{\mathrm{H}-\mathrm{H}}=7.8 \mathrm{~Hz}\right), 7.41\left(\mathrm{~d}, 2 \mathrm{H},{ }^{3} \mathrm{~J}_{\mathrm{H}-\mathrm{H}}=7.1 \mathrm{~Hz}\right.$, biphenylene- $\left.\mathrm{CH}\right), 7.37\left(\mathrm{t}, 2 \mathrm{H},{ }^{3} \mathrm{~J}_{\mathrm{H}-\mathrm{H}}=\right.$ $7.6 \mathrm{~Hz}$, biphenylene- $\mathrm{CH}), 6.98\left(\mathrm{~d}, 2 \mathrm{H},{ }^{3} \mathrm{~J}_{\mathrm{H}-\mathrm{H}}=8.1 \mathrm{~Hz}\right.$, biphenylene- $\left.\mathrm{CH}\right) \mathrm{ppm} .{ }^{13} \mathrm{C}$ NMR $(125.62 \mathrm{MHz}$, 
$\left.25{ }^{\circ} \mathrm{C}, \mathrm{CD}_{3} \mathrm{CN}\right): \delta 171.29,158.34,153.49,152.06,146.53,145.94132 .93,132.28,131.78,131.35$, $123.06,121.12,119.73 \mathrm{ppm}$. A resonance for one of the quaternary carbon centers was not observed. UV-vis: $\varepsilon=1.83 \times 10^{5} \mathrm{M}^{-1} . \mathrm{cm}^{-1}$ at $\lambda=260 \mathrm{~nm}, \varepsilon=2.50 \times 10^{4} \mathrm{M}^{-1} \cdot \mathrm{cm}^{-1}$ at $\lambda=346 \mathrm{~nm}, \varepsilon=$ $3.95 \times 10^{4} \mathrm{M}^{-1} \cdot \mathrm{cm}^{-1}$ at $\lambda=361 \mathrm{~nm}, \varepsilon=3.63 \times 10^{4} \mathrm{M}^{-1} \cdot \mathrm{cm}^{-1}$ at $\lambda=371 \mathrm{~nm}$. Elemental analysis calculated (\%) for $\mathrm{C}_{38} \mathrm{H}_{22} \mathrm{~B}_{2} \mathrm{~F}_{8} \mathrm{O}_{2}$ : C, 66.71; H, 3.24; found C, 66.84; H, 3.21. Single crystals of $[3]\left[\mathrm{BF}_{4}\right]_{2}-\left(\mathrm{CH}_{3} \mathrm{CN}\right)_{2}$ were obtained by diffusion of ether into an MeCN solution of the salt.

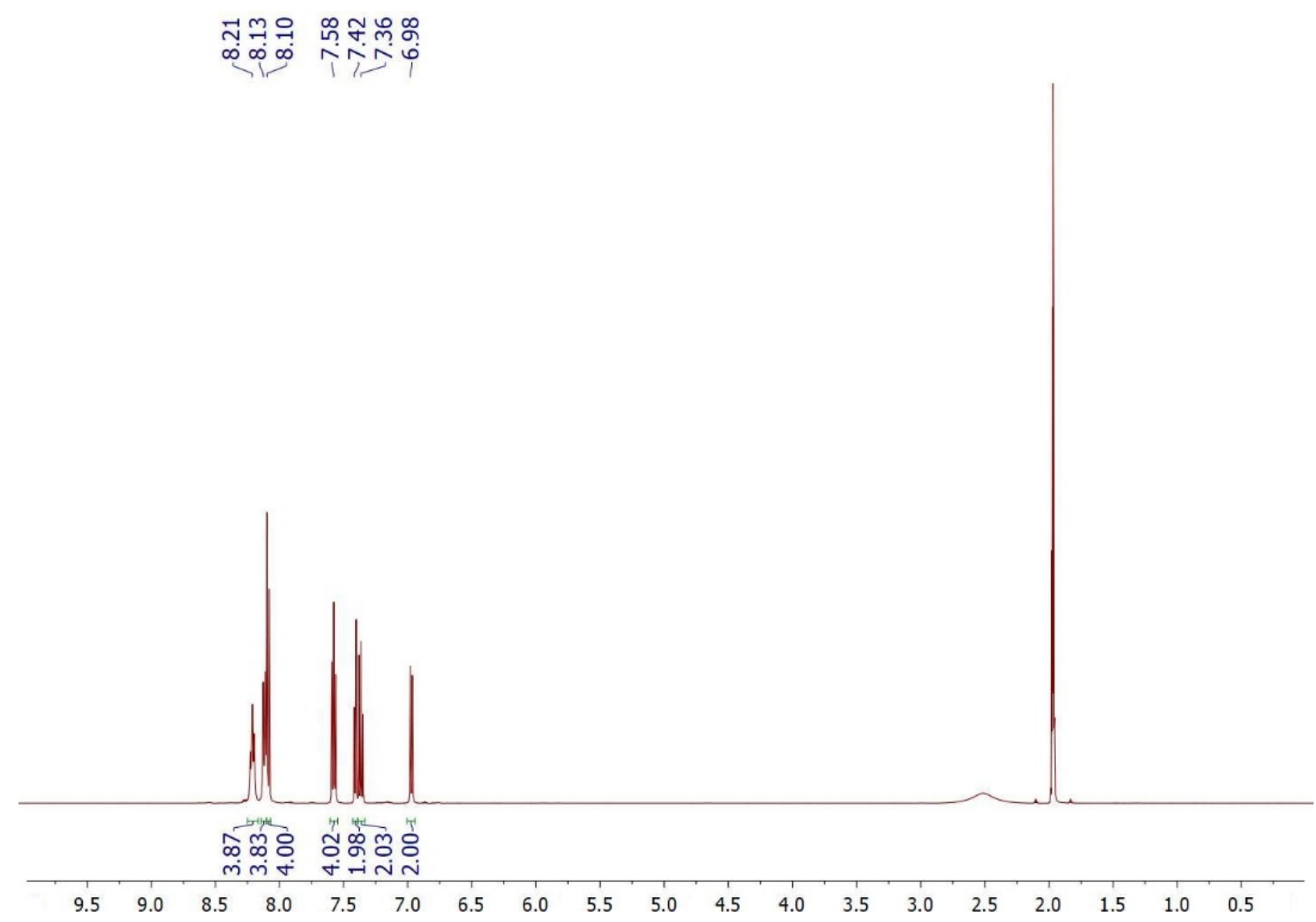

Figure S1: ${ }^{1} \mathrm{H}-\mathrm{NMR}$ spectrum of $[3]\left[\mathrm{BF}_{4}\right]_{2}$ in $\mathrm{CD}_{3} \mathrm{CN}$ 


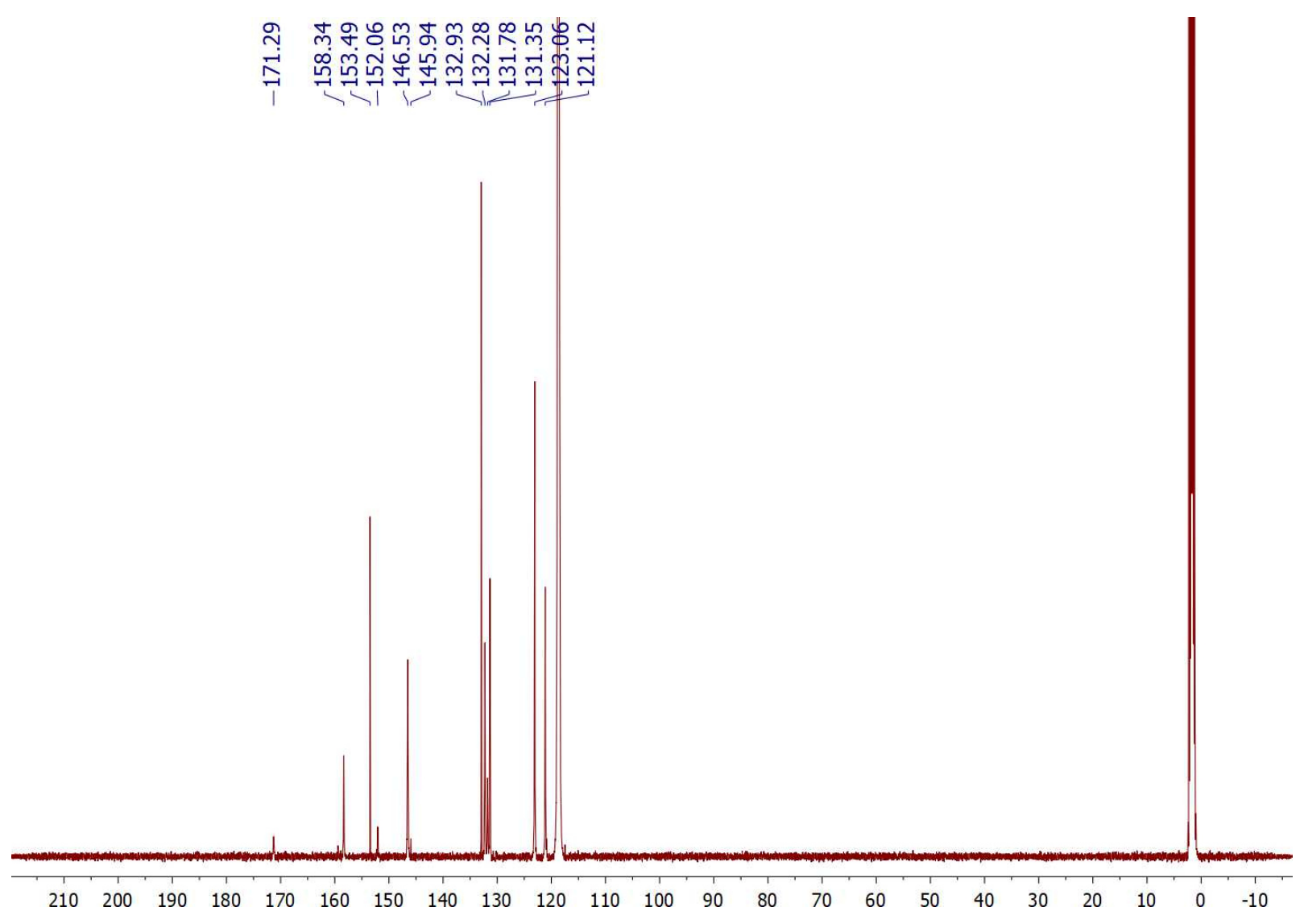

Figure S2: ${ }^{33} \mathrm{C}-\mathrm{NMR}$ spectrum of $[3]\left[\mathrm{BF}_{4}\right]_{2}$ in $\mathrm{CD}_{3} \mathrm{CN}$

Synthesis of $[4]\left[\mathrm{BF}_{4}\right]_{2}$ :

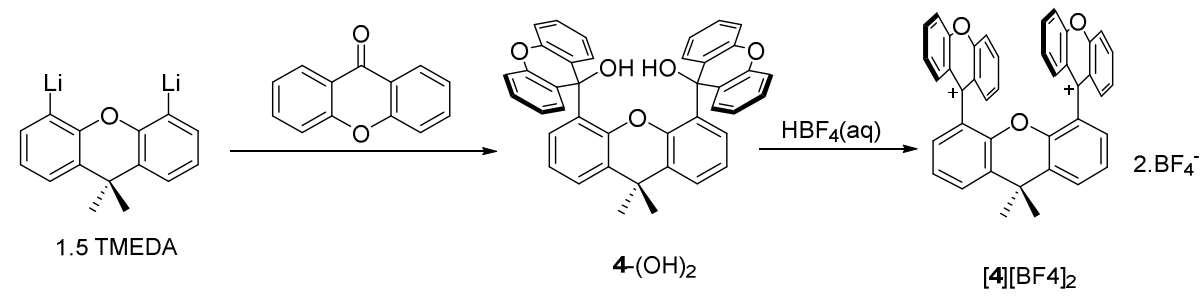

4,5-dilithio-9,9-dimethylxanthene ( $500.0 \mathrm{mg}, 1.27 \mathrm{mmol}$ ) was suspended in $15 \mathrm{~mL}$ freshly distilled $\mathrm{Et}_{2} \mathrm{O}$. Xanthone ( $\left.498.7 \mathrm{mg}, 2.54 \mathrm{mmol}\right)$ was dissolved in the smallest amount of $\mathrm{Et}_{2} \mathrm{O}$ possible $(\sim 7$ $\mathrm{mL}$ ) and transferred to the reaction mixture, which resulted in the initial brown-yellow color of the suspension to turn dark and all of the precipitate to dissolve. The solution was then stirred for $16 \mathrm{~h}$, during which a white precipitate gradually crashed out. Then the mixture was exposed to air and 1 mL saturated $\mathrm{NH}_{4} \mathrm{Cl}_{(\mathrm{aq})}$ was slowly added and the mixture was stirred for 30 minutes. The volatiles were removed under vacuum and the mixture was extracted with $15 \mathrm{~mL} \mathrm{CH}_{2} \mathrm{Cl}_{2}$. The aqueous phase was further extracted with $2 \times 10 \mathrm{~mL} \mathrm{CH}_{2} \mathrm{Cl}_{2}$. The organic solutions were combined and dried over $\mathrm{Na}_{2} \mathrm{SO}_{4}$. Evaporation of the solvent yielded a slightly oily pale yellow residue which showed $\sim 75 \%$ conversion to the corresponding dicarbinol in ${ }^{1} \mathrm{H}-\mathrm{NMR}$. The residue was then purified by column 
chromatography to yield 4- $(\mathrm{OH})_{2}$ as a crude product ( $452 \mathrm{mg}, \sim 59 \%$ yield). This compound was analyzed by ${ }^{1} \mathrm{H}-\mathrm{NMR}$ spectroscopy in $\mathrm{CDCl}_{3}(\delta 7.88(\mathrm{~d}, J=7.5 \mathrm{~Hz}, 4 \mathrm{H}), 7.33(\mathrm{~d}, J=7.8 \mathrm{~Hz}, 2 \mathrm{H}), 7.29(\mathrm{t}$, $J=7.6 \mathrm{~Hz}, 4 \mathrm{H}), 7.17(\mathrm{~d}, J=8.1 \mathrm{~Hz}, 4 \mathrm{H}), 7.12(\mathrm{t}, J=7.5 \mathrm{~Hz} 4 \mathrm{H}), 6.89(\mathrm{~d}, J=7.8 \mathrm{~Hz} 2 \mathrm{H}), 6.53(\mathrm{~d}, J=7.8$ $\mathrm{Hz} 2 \mathrm{H}), 5.30(\mathrm{~s}, 2 \mathrm{H}), 1.67(\mathrm{~s}, 6 \mathrm{H}))$ and was used without further purification as described hereafter. $\mathrm{HBF}_{4(\mathrm{aq})}(50 \% \mathrm{w} / \mathrm{w}, 0.8 \mathrm{~mL}, 4.35 \mathrm{mmol})$ was added to a suspension of 4- $(\mathrm{OH})_{2}(211 \mathrm{mg}, 0.35 \mathrm{mmol})$ in $\mathrm{MeCN}(5 \mathrm{~mL})$, resulting in immediate dissolution of the residue and evolution of a dark red color. The solution was then stirred for 30 minutes and the volatiles were removed under vacuum, giving a very dark red sticky residue. Trituration of the residue with $5 \times 5 \mathrm{~mL} \mathrm{Et}_{2} \mathrm{O}$ afforded [4][BF $]_{2}$ as a reddish dark brown powder (184 mg, 70\% yield). ${ }^{1} \mathrm{H}-\mathrm{NMR}\left(499.55 \mathrm{MHz}, \mathrm{CD}_{3} \mathrm{CN}\right): \delta 8.26(\mathrm{~m}, 8 \mathrm{H})$, $8.08(\mathrm{~d}, J=8.0 \mathrm{~Hz}, 2 \mathrm{H}), 7.75(\mathrm{~d}, J=8.4 \mathrm{~Hz}, 4 \mathrm{H}), 7.51(\mathrm{~m}, 6 \mathrm{H}), 7.22(\mathrm{~d}, J=7.4 \mathrm{~Hz} 2 \mathrm{H}), 2.00(\mathrm{~s}, 6 \mathrm{H}) .{ }^{13} \mathrm{C}-$ NMR $\left(125.62 \mathrm{MHz}, \mathrm{CD}_{3} \mathrm{CN}\right) \delta 173.17,158.12,146.10,133.04,132.60,131.87,130.72,130.27$,

125.68, 124.10, 120.43, 119.12, 35.77, 33.63. ${ }^{19} \mathrm{~F}-\mathrm{NMR}\left(470.38 \mathrm{MHz}, \mathrm{CD}_{3} \mathrm{CN}\right): \delta-149.65$. UV-vis: $\varepsilon=$ $7.18 \times 10^{4} \mathrm{M}^{-1} \cdot \mathrm{cm}^{-1}$ at $\lambda=255 \mathrm{~nm}, \varepsilon=4.62 \times 10^{4} \mathrm{M}^{-1} \cdot \mathrm{cm}^{-1}$ at $\lambda=364 \mathrm{~nm}, \varepsilon=7.18 \times 10^{3} \mathrm{M}^{-1} \cdot \mathrm{cm}^{-1}$ at $\lambda=$ $457 \mathrm{~nm}$. Elemental analysis calculated (\%) for $\mathrm{C}_{41} \mathrm{H}_{28} \mathrm{~B}_{2} \mathrm{~F}_{8} \mathrm{O}_{3}: \mathrm{C}, 66.34 ; \mathrm{H}, 3.80$; found $\mathrm{C}, 66.15 ; \mathrm{H}$, 3.94. Single crystals of $[4]\left[\mathrm{BF}_{4}\right]_{2}-\left(\mathrm{Et}_{2} \mathrm{O}\right)-\left(\mathrm{CH}_{3} \mathrm{CN}\right)$ were obtained by diffusion of ether into an $\mathrm{MeCN}$ solution of the salt. These crystals grew as very thin plates, which complicated their analysis.

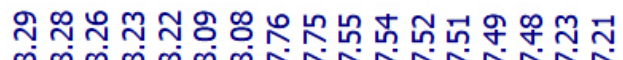
$\infty \infty \infty \infty \infty \infty \infty N+N$

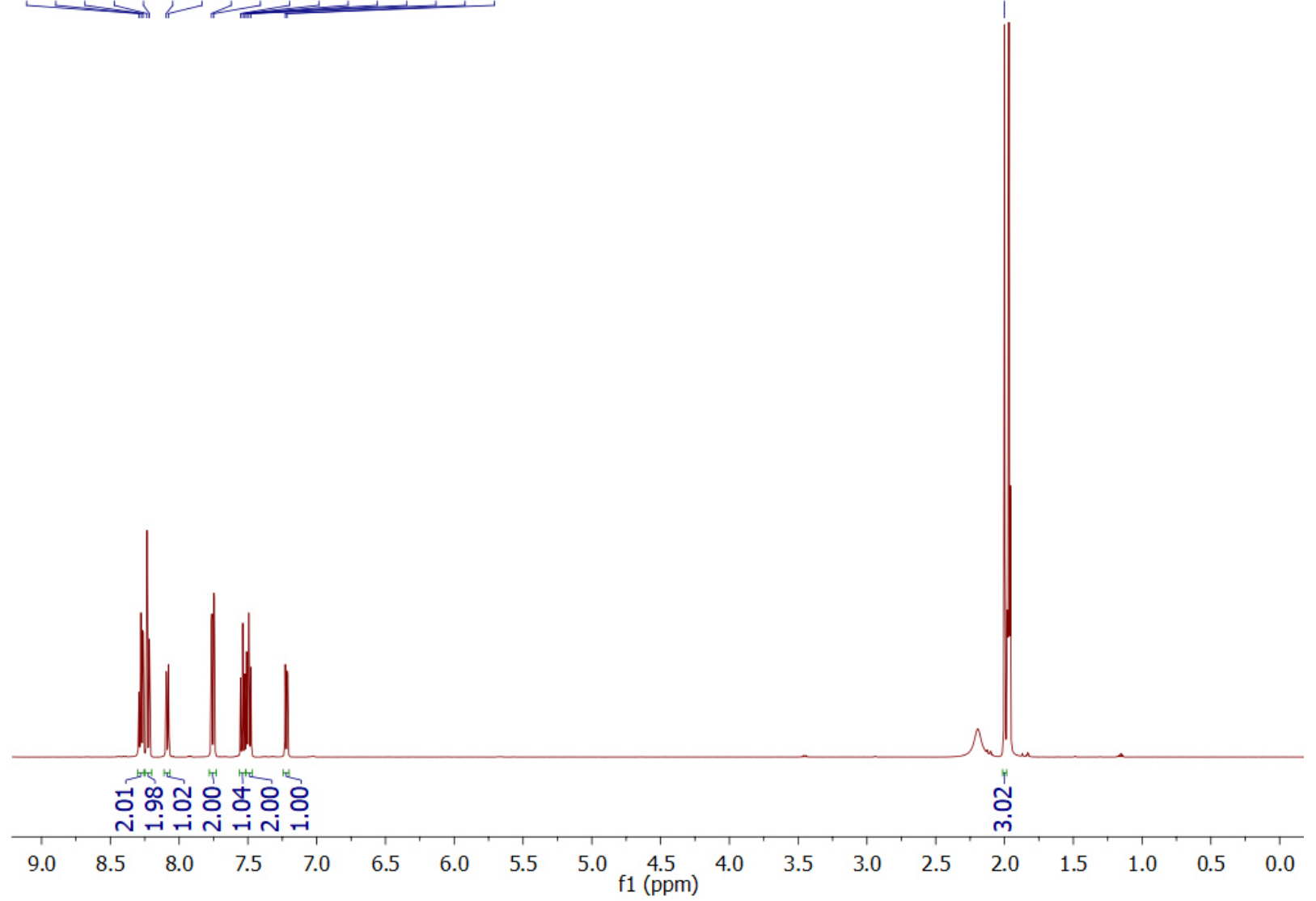

Figure S3: ${ }^{1} \mathrm{H}-\mathrm{NMR}$ spectrum of $[4]\left[\mathrm{BF}_{4}\right]_{2}$ in $\mathrm{CD}_{3} \mathrm{CN}$ 


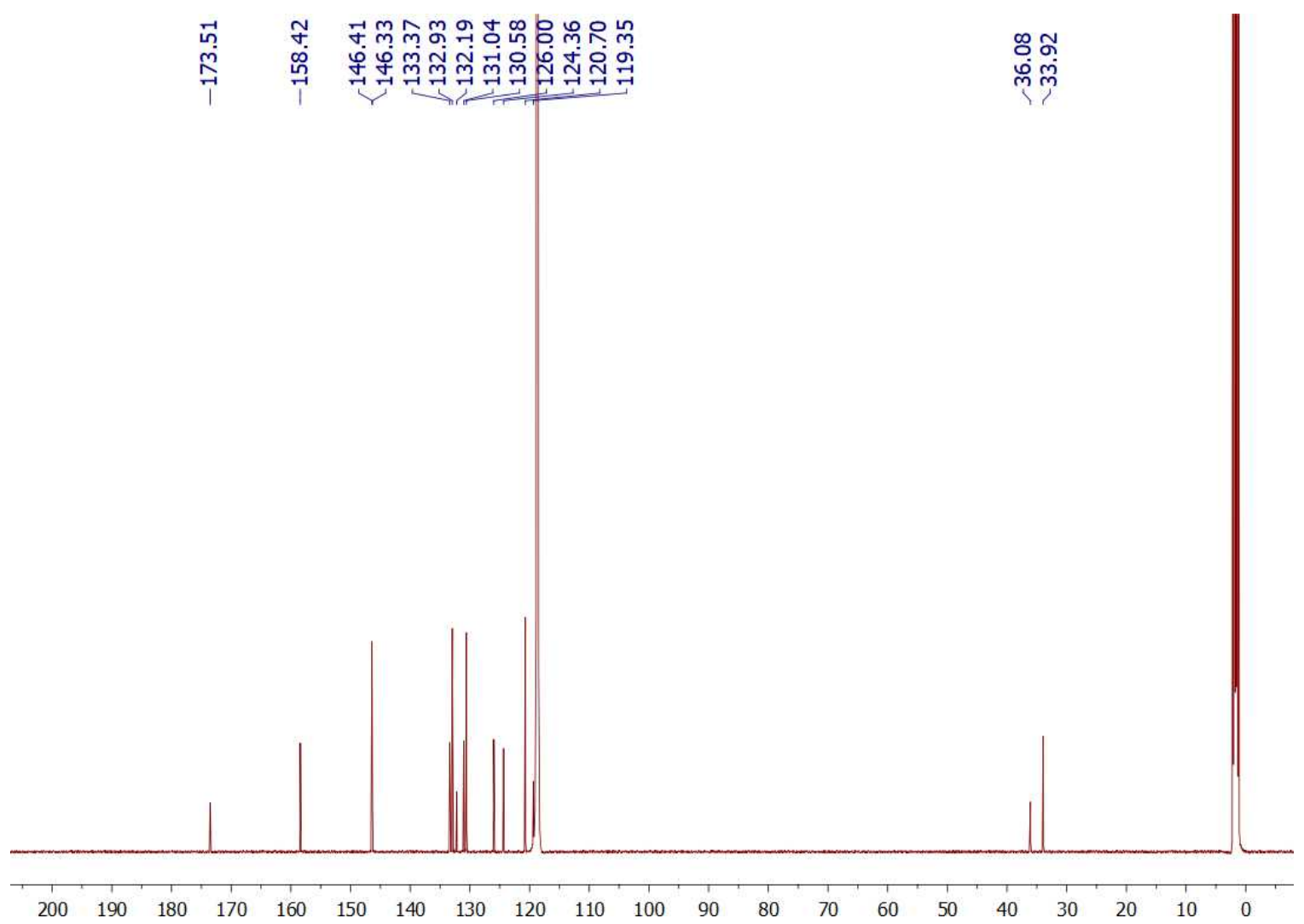

Figure S4: ${ }^{13} \mathrm{C}$-NMR spectrum of $[4]\left[\mathrm{BF}_{4}\right]_{2}$ in $\mathrm{CD}_{3} \mathrm{CN}$

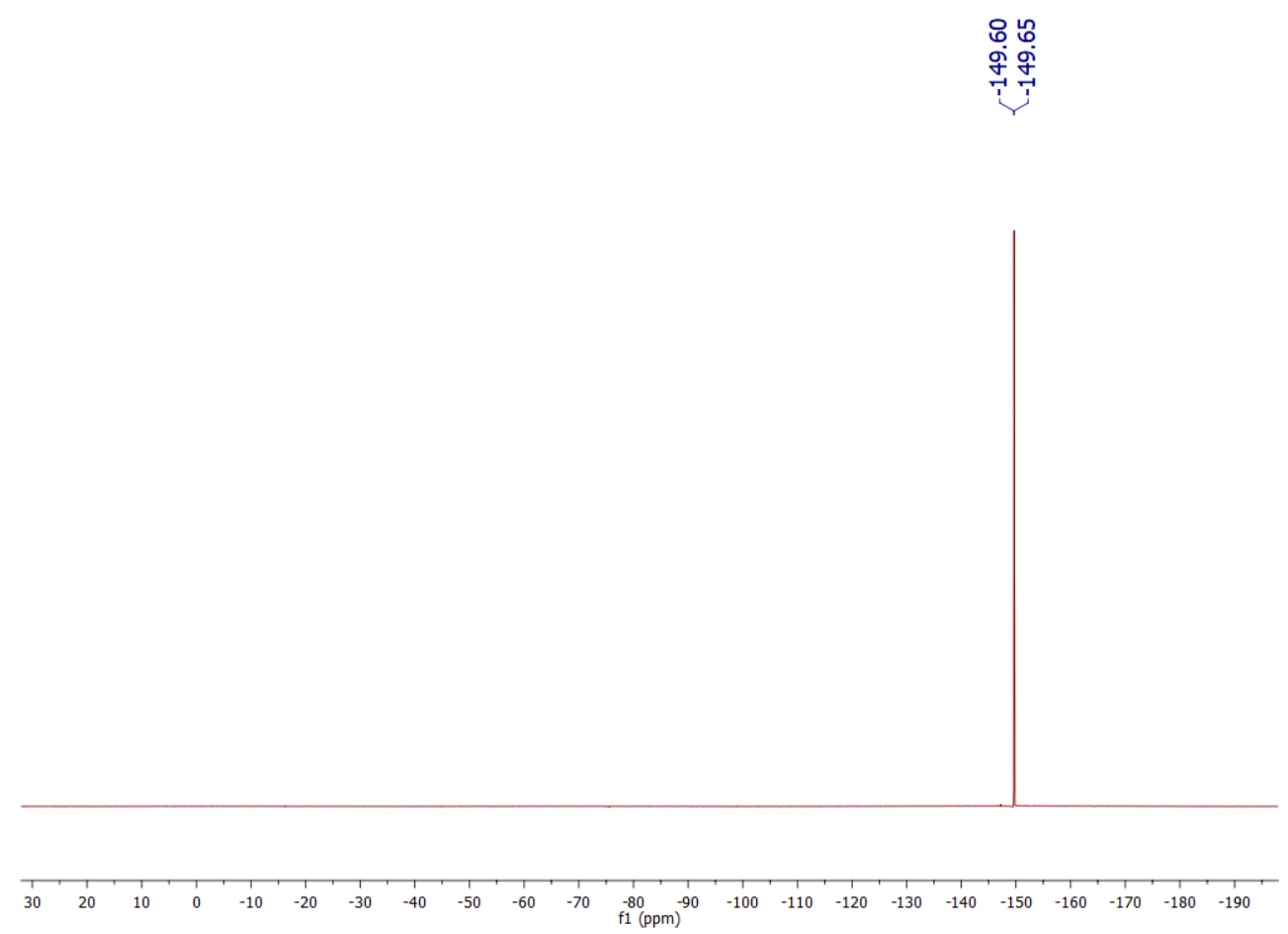

Figure S5: ${ }^{19} \mathrm{~F}-\mathrm{NMR}$ spectrum of $[4]\left[\mathrm{BF}_{4}\right]_{2}$ in $\mathrm{CD}_{3} \mathrm{CN}$ 


\section{Generation of 4- $0_{2}$ as observed by ${ }^{1} \mathrm{H}$ NMR spectroscopy}

$\mathrm{A} \mathrm{CD}_{3} \mathrm{CN}$ solution of $[4]\left[\mathrm{BF}_{4}\right]_{2}(20 \mathrm{mg}, 26 \mu \mathrm{mol})$ was loaded in an NMR tube containing a 10 fold excess of Zn powder (17.5 mg, $260 \mu \mathrm{mol})$. The solution was sonicated and manually agitated for 1 $\mathrm{h}$, during which time the characteristic red color of the dication faded away and a pale yellow precipitate formed. The mixture was transferred to a vial and brought to dryness under vacuum. The resulting residue was taken up in $\mathrm{C}_{6} \mathrm{D}_{6}$, filtered and transferred into an NMR tube for spectroscopic analysis (middle spectrum in Figure $\mathrm{S} 6$ ). The $\mathrm{C}_{6} \mathrm{D}_{6}$ solution was transferred to a vial and brought to dryness under vacuum. The resulting residue was taken up in $\mathrm{CD}_{3} \mathrm{CN}$ and treated with excess aqueous $\mathrm{HBF}_{4}$. The resulting mixture was transferred to an NMR tube for spectroscopic analysis (top spectrum in Figure S6). The spectra collected are consistent with the formation 4- $\mathrm{O}_{2}$ and its protonolysis back into $[4]^{2+}$.
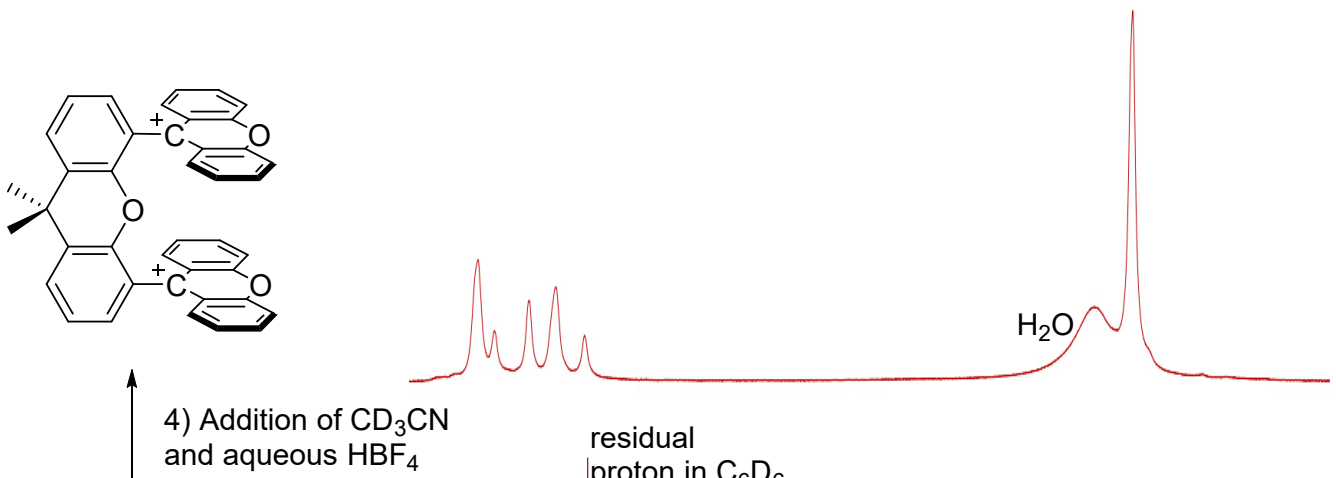
and aqueous $\mathrm{HBF}_{4}$ proton in $\mathrm{C}_{6} \mathrm{D}_{6}$

3) Evaporation of the $\mathrm{C}_{6} \mathrm{D}_{6}$
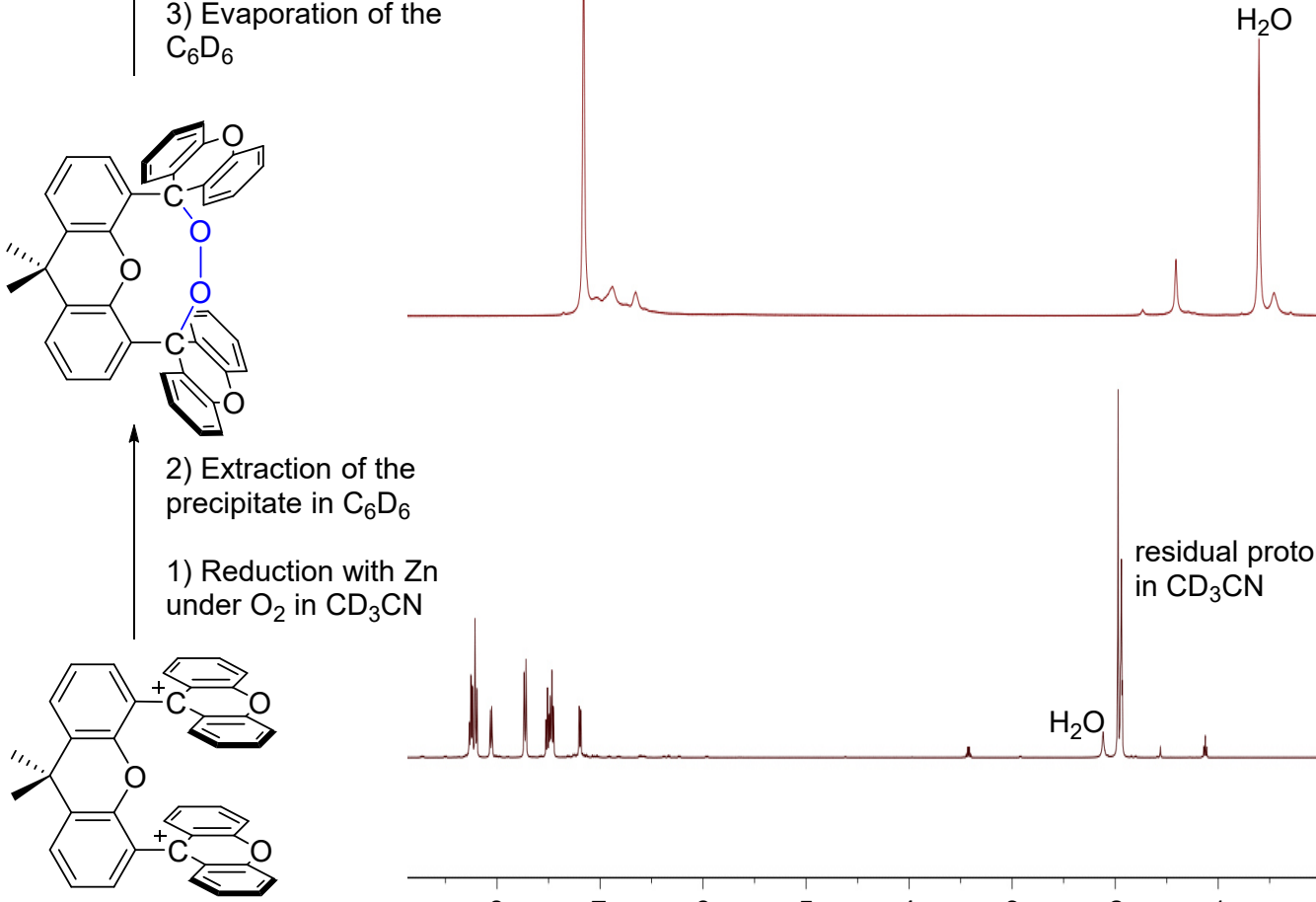

Extraction of the recipitate in $\mathrm{C}_{6} \mathrm{D}_{6}$

1) Reduction with $\mathrm{Zn}$

residual proton in $\mathrm{CD}_{3} \mathrm{CN}$

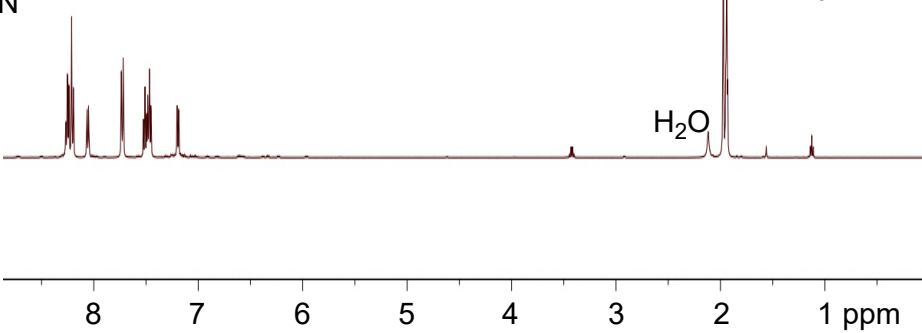

Figure S6: NMR spectra of $[4]\left[\mathrm{BF}_{4}\right]_{2}$ (bottom spectrum), its conversion into 4- $\mathrm{O}_{2}$ after reaction with $\mathrm{Zn}$ powder (middle spectrum), and it conversion back into [4] $\left[\mathrm{BF}_{4}\right]_{2}$ after treatment with $\mathrm{HBF}_{4}$ (top spectrum). 


\section{Catalyst screening:}

The general method followed was adapted from previous proceedings ${ }^{5}$. Solution A was prepared by mixing $5.0 \mu \mathrm{L}$ of a $1.00 \mathrm{M}$ methanesulfonic acid $\left(\mathrm{MeSO}_{3} \mathrm{H}\right)$ in $\mathrm{MeCN}$ with $10.0 \mu \mathrm{L}$ of a $1.0 \mathrm{mM}$ solution of the catalyst in MeCN and diluting to $1.80 \mathrm{~mL}$ inside a UV cuvette $(\mathrm{b}=1.0 \mathrm{~cm})$, followed by purging with $\mathrm{O}_{2}$ for 2 minutes. Solution $\mathrm{B}$ was prepared by sparging $1.20 \mathrm{~mL}$ of a $0.9 \mathrm{mM}$ solution of $\mathrm{Fc}^{*}$ with $\mathrm{O}_{2}$ for 2 minutes. Solutions $\mathrm{A}$ and $\mathrm{B}$ were sparged with $\mathrm{O}_{2}$ at the same time. Solution $B$ was then rapidly mixed with solution $A$ in the cuvette for 10 seconds and the absorbance at $780 \mathrm{~nm}$ due to evolution of $\mathrm{Fc}^{*+}$ was monitored thereafter.

The same procedure was then carried out for a blank solution containing no catalyst to evaluate the background $\mathrm{O}_{2}$ reduction. Initial rates were determined by subtraction of the absorbances from the background uncatalyzed $\mathrm{O}_{2}$ reduction, from the absorbances of the catalytic runs in the first $\sim 10 \%$ of the reaction time. Turnover Frequency (TOF, $\mathrm{s}^{-1}$ ) values were determined by dividing the obtained initial rates by the catalyst concentration according to equation 1 . The catalytic and background reactions were run in triplicate and the obtained TOFs were averaged. The obtained values for $[1]\left[\mathrm{BF}_{4}\right],[2]\left[\mathrm{BF}_{4}\right]_{2},[3]\left[\mathrm{BF}_{4}\right]_{2}$, and $[4]\left[\mathrm{BF}_{4}\right]_{2}$ are $6.7( \pm 0.3) \times 10^{-3} \mathrm{~s}^{-1}, 2.6( \pm 0.2) \times 10^{-2} \mathrm{~s}^{-1}, 5.7$ $( \pm 0.2) \times 10^{-2} \mathrm{~s}^{-1}$, and $6.1( \pm 0.1) \times 10^{-1} \mathrm{~s}^{-1}$.

$T O F=\frac{\text { initial ORR rate }}{[\text { cat }]}$

Using a catalyst loading of $1.08 \%$, the turnover number (TON) can be calculated using equation 2 :

TON $=\frac{\text { number of moles of } F c^{*}}{2 \times \text { number of moles of catalyst }}$

This yields a TON of 54 for all four of the cations studied under the conditions described above.

\section{Comparison of rates in the presence and absence of $\mathrm{H}_{2} \mathrm{O}_{2}$ and buffer}

In order to establish a reference state for the overpotential analysis presented in section $\mathrm{X}, \mathrm{H}_{2} \mathrm{O}_{2}$ and $\mathrm{MeSO}_{3}$ - must exist in the reaction solution, to satisfy the requirements set by the Nernst equation. Therefore, $\mathrm{DABCO} . \mathrm{H}_{2} \mathrm{O}_{2}$ and $\mathrm{NaMeSO}_{3}$ were added to the reaction mixtures at concentrations of $1.0 \mathrm{mM}$ and $1.66 \mathrm{mM}$ respectively, and UV-Vis time course graphs were obtained as described above (Figure S7). The same conditions were employed for background $\mathrm{O}_{2}$ reduction. The background profile was then subtracted from the time course graphs obtained for [4][BF $]_{2}$ to yield TOF values of $0.62 \mathrm{~s}^{-1}$ and $0.61 \mathrm{~s}^{-1}$ and $0.63 \mathrm{~s}^{-1}$, giving an average of $0.62 \mathrm{~s}^{-1}$, which is in excellent agreement with the value obtained without $\mathrm{NaMeSO}_{3}$ and $\mathrm{DABCO} \cdot \mathrm{H}_{2} \mathrm{O}_{2}$.

In order to eliminate the possibility of $\mathrm{H}_{2} \mathrm{O}_{2}$ consumption or reaction with $\mathrm{DABCO}$, they were tested independently following the above procedure, and were shown to not influence the time course graphs obtained in their absence. 

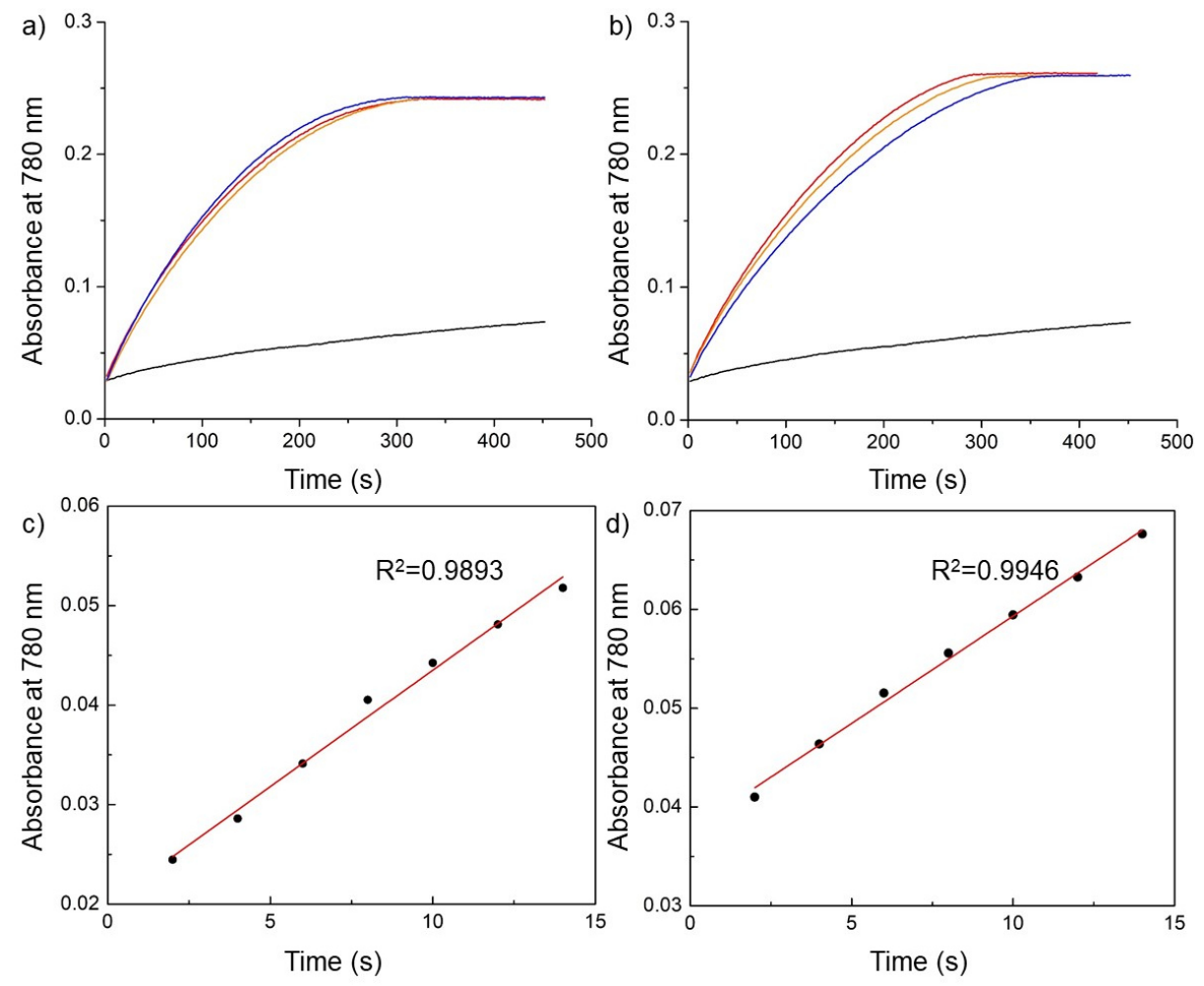

Figure S7: UV-Vis time course graphs obtained for catalytic $\mathrm{O}_{2}$ reduction by $\mathrm{Fc}^{*}$ and $\mathrm{MeSO}_{3} \mathrm{H}$ using [4] $\left[\mathrm{BF}_{4}\right]_{2}$ in the presence (a) and absence (b) of $1.0 \mathrm{mM} \mathrm{DABCO} . \mathrm{H}_{2} \mathrm{O}_{2}$ and $1.66 \mathrm{mM} \mathrm{NaMeSO}_{3}$. Linear regression fit of the background-corrected absorptions in the first $\sim 10 \%$ of reaction time, in the presence (c) and absence (d) of $1.0 \mathrm{mM} \mathrm{DABCO} . \mathrm{H}_{2} \mathrm{O}_{2}$ and $1.66 \mathrm{mM} \mathrm{NaMeSO}_{3}$. Reaction conditions: catalyst concentration $3.33 \mu \mathrm{M},\left[\mathrm{MeSO}_{3} \mathrm{H}\right] 1.66 \mathrm{mM},\left[\mathrm{Fc}^{*}\right] 0.36 \mathrm{mM}$, in $\mathrm{O}_{2}$-saturated $\mathrm{MeCN}$.

\section{Iodometric titration for the determination of $\mathrm{H}_{2} \mathrm{O}_{2}$ :}

\section{A. Characterization of $\mathrm{H}_{2} \underline{\mathrm{O}}_{2}$ formed catalytically}

The concentration of $\mathrm{H}_{2} \mathrm{O}_{2}$ was determined by spectrophotometric titration of the reaction mixture with $\mathrm{NaI}$ in the absence of $\mathrm{O}_{2}$, as previously described in the literature. ${ }^{6-8}$

$3 \mathrm{NaI}+\mathrm{H}_{2} \mathrm{O}_{2} \rightarrow 2 \mathrm{NaOH}+\mathrm{NaI}_{3}$

First, catalytic runs were carried out as described in section IV. For each catalyst, once the reaction was complete and no change in absorption at $780 \mathrm{~nm}$ was observed for 30 minutes, the solution was sparged with $\mathrm{N}_{2}$ to remove all $\mathrm{O}_{2}$, then two $300 \mu \mathrm{L}$ aliquots of the resulting solution were taken and transferred to two modified UV cells (path length $=1.0 \mathrm{~cm}$ ) equipped with Teflon screw caps. The first solution was diluted to $2.95 \mathrm{~mL}$ using degassed MeCN. $50 \mu \mathrm{L}$ ( $\sim 600$ equivalents assuming that selectivity for $\mathrm{H}_{2} \mathrm{O}_{2}$ is $100 \%$ ) of a saturated $\mathrm{NaI}$ solution in MeCN (prepared in the absence of $\mathrm{O}_{2}$ ) was added and the mixture was shaken for 5 minutes and the UV-Vis spectrum was recorded. The second solution was diluted to $3.00 \mathrm{~mL}$ using degassed $\mathrm{MeCN}$ and its UV-Vis spectrum was recorded. The difference in the absorbances at $361 \mathrm{~nm}$ between the spectra obtained with and 
without added iodide (Figure S8) is ascribed to the triiodide anion $\left(\lambda_{\max }=361 \mathrm{~nm}, \epsilon=2.8 \times 10^{4} \mathrm{~mol}^{-}\right.$ $\left.1 . \mathrm{cm}^{-1}\right) .8$
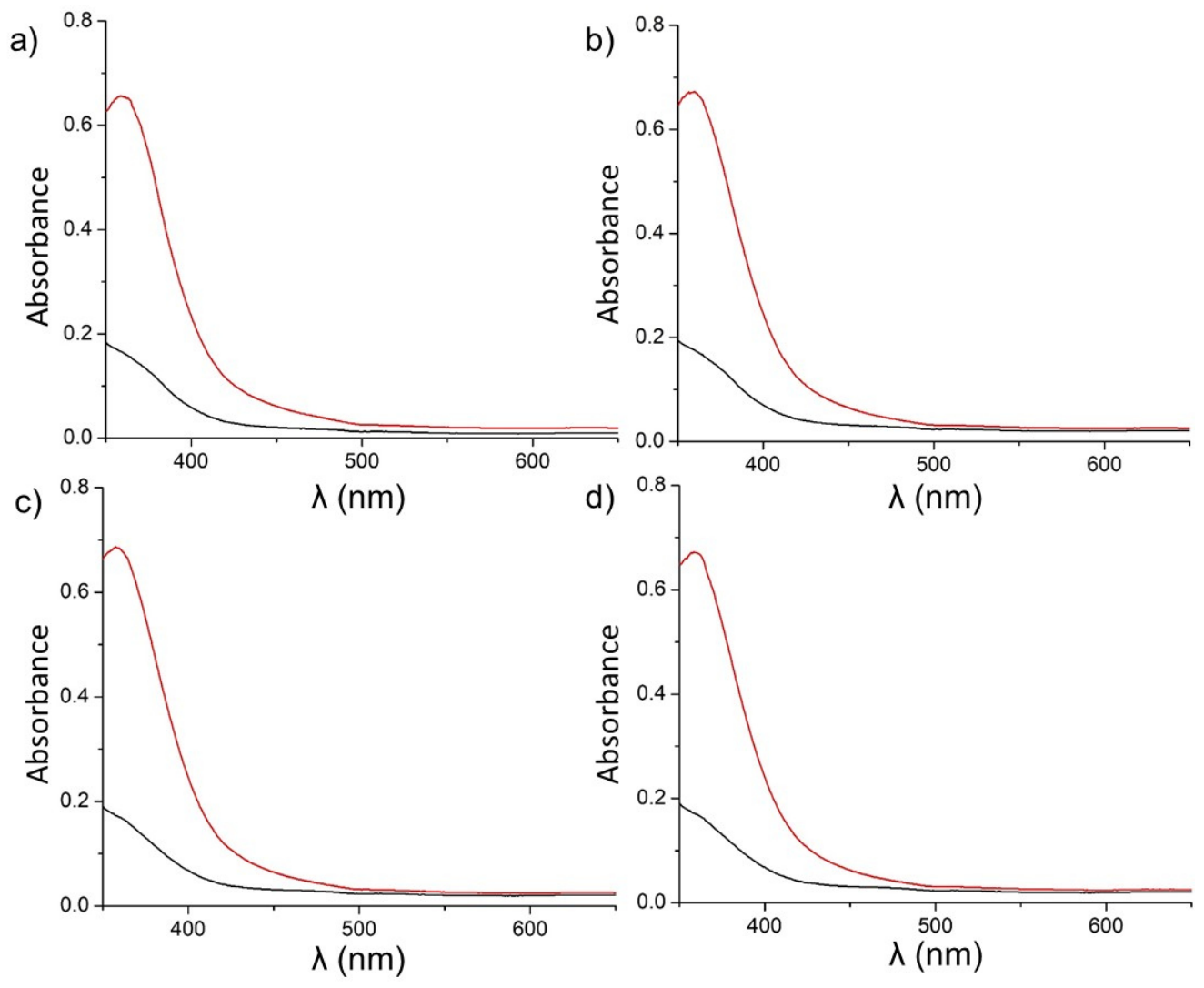

Figure S8: UV-Vis spectra of the diluted catalytic reaction mixtures with and without excess NaI (red and black traces respectively) for (a) $[1]\left[\mathrm{BF}_{4}\right](\mathrm{b})[2]\left[\mathrm{BF}_{4}\right]_{2}(\mathrm{c})[3]\left[\mathrm{BF}_{4}\right]_{2}$ (d) $[4]\left[\mathrm{BF}_{4}\right]_{2}$.

The experimental concentration of $\mathrm{H}_{2} \mathrm{O}_{2}$ can be obtained by subtraction of the black traces from the red traces in Figure S8, according to equation 3:

$\frac{A_{361}^{2}-A_{361}^{1}}{\epsilon . b}=C_{\text {triiodide }}=C_{H 2 O 2}$

The theoretical concentration of $\mathrm{H}_{2} \mathrm{O}_{2}$ can be calculated as follows:

$2 \mathrm{Fc}^{*}+\mathrm{O}_{2}+2 \mathrm{H}^{+} \stackrel{\text { Cat. }}{\longrightarrow} \mathrm{H}_{2} \mathrm{O}_{2}+2 \mathrm{Fc}^{*+}$

$1.2 \mathrm{~mL} \times 9.0 \times 10^{-4} \mathrm{MFC}^{*} \times \frac{1 \mathrm{~mol} \mathrm{H} 2 \mathrm{O} 2}{2 \mathrm{~mol} \mathrm{FC^{* }}} \times \frac{1}{3.00 \mathrm{~mL}}=C_{H 2 O 2}^{\prime}$

$\%$ selectivity $\mathrm{H} 2 \mathrm{O} 2=\frac{C_{H 2 O 2}}{C_{H 2 O 2}^{\prime}} \times 100 \%$

Selectivities were thus determined to be $93 \%, 94 \%, 95 \%$, and $97 \%$ for $[\mathbf{1}]\left[\mathrm{BF}_{4}\right],[2]\left[\mathrm{BF}_{4}\right]_{2},[3]\left[\mathrm{BF}_{4}\right]_{2}$, and $[4]\left[\mathrm{BF}_{4}\right]_{2}$ respectively.

B. Control experiments 
It has previously been established that $\mathrm{Fc}^{*+}$ does not oxidize $\mathrm{I}^{-5}$ The possibility of a reaction between I- and [4] $\left[\mathrm{BF}_{4}\right]_{2}$ in the absence of $\mathrm{O}_{2}$ was probed by taking $10 \mu \mathrm{L}$ of a $\mathrm{N}_{2}$ saturated $1.0 \mathrm{mM}$ solution of [4] $\left[\mathrm{BF}_{4}\right]_{2}$ in the aforementioned modified UV cell, followed by addition of $5.0 \mu \mathrm{L}$ of $1.0 \mathrm{M}$ $\mathrm{MeSO}_{3} \mathrm{H}$, and diluting to $2.95 \mathrm{~mL}$ using degassed MeCN. $50 \mu \mathrm{L}$ of the NaI solution was then added and the absorbance at $361 \mathrm{~nm}$ was monitored for 30 minutes, during which time no change was observed.

\section{UV-Vis kinetic studies:}

$2 \mathrm{Fc}^{*}+\mathrm{O}_{2}+2 \mathrm{H}^{+} \stackrel{\text { Cat. }}{\longrightarrow} \mathrm{H}_{2} \mathrm{O}_{2}+2 \mathrm{Fc}^{*+}$

The concentrations of each of the components of the catalytic reaction were systematically varied and the initial rate of the reaction was determined. The experimental procedure undertaken is similar to previously reported proceedings ${ }^{5}$. In general, the concentrations selected for this study follow a pseudo-first order trend with $\mathrm{Fc}^{*}$ being turnover-limiting: [cat $] \ll\left[\mathrm{Fc}^{*}\right]<\left[\mathrm{H}^{+}\right]<\left[\mathrm{O}_{2}\right]$

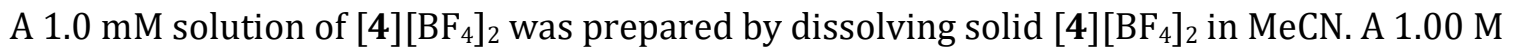
solution of $\mathrm{MeSO}_{3} \mathrm{H}$ was prepared by diluting the pure acid in MeCN. A $0.9 \mathrm{mM}$ solution of Fc* was prepared by dissolving solid $\mathrm{Fc}^{*}$ in $\mathrm{MeCN}$. The concentration of $\mathrm{O}_{2}$ in $\mathrm{MeCN}$ was determined from the literature. ${ }^{9-10}$

Generally, [4] $\left[\mathrm{BF}_{4}\right]_{2}$ and $\mathrm{MeSO}_{3} \mathrm{H}$ were mixed in a UV cell and diluted with MeCN and sparged vigorously with $\mathrm{O}_{2}$ for 2 minutes. $\mathrm{Fc}^{*}$ was taken in a vial and sparged with $\mathrm{O}_{2}$ for 2 minutes at the same time, and then injected into the UV cell as rapidly as possible with vigorous stirring and agitation to minimize the diffusion effects on the initial reaction rate, and the absorbance of the product $\mathrm{Fc}^{*+}$ was monitored at $780 \mathrm{~nm}$. For every data point, the experiment was conducted at least 3 times to give average values and estimated errors.

$[4]\left[\mathrm{BF}_{4}\right]_{2}$

5.0, 7.5,10.0, and $12.5 \mu \mathrm{L}$ of the $1.0 \mathrm{mM}$ solution of $[4]\left[\mathrm{BF}_{4}\right]_{2}$ was mixed with $5.0 \mu \mathrm{L} \mathrm{MeSO}_{3} \mathrm{H} 1.00 \mathrm{M}$ and diluted to $1.80 \mathrm{~mL}$ with $\mathrm{MeCN}$ and sparged with $\mathrm{O}_{2}$ for 2 minutes. $1.20 \mathrm{~mL}$ of the Fc* solution was simultaneously sparged with $\mathrm{O}_{2}$. The two solutions were forcefully mixed in a UV cell for 10 seconds. A selection of the time course graphs obtained are presented in Figure S9 (a).

$\left[\mathrm{MeSO}_{3} \mathrm{H}\right]$

$10.0 \mu \mathrm{L}$ of the $1.0 \mathrm{mM}$ solution of $[4]\left[\mathrm{BF}_{4}\right]_{2}$ was mixed with $2.5,5.0,7.5,10.0 \mu \mathrm{L} \mathrm{MeSO}_{3} \mathrm{H} 1.00 \mathrm{M}$ and diluted to $1.80 \mathrm{~mL}$ with MeCN and sparged with $\mathrm{O}_{2}$ for 2 minutes. $1.20 \mathrm{~mL}$ of the $\mathrm{Fc}^{*}$ solution was simultaneously sparged with $\mathrm{O}_{2}$. The two solutions were forcefully mixed in a UV cell for 10 seconds. A selection of the time course graphs obtained are presented in Figure S9 (b).

$\left[\mathrm{FC}^{*}\right]$

$10.0 \mu \mathrm{L}$ of the $1.0 \mathrm{mM}$ solution of $[4]\left[\mathrm{BF}_{4}\right]_{2}$ was mixed with $5.0 \mu \mathrm{L} \mathrm{MeSO}{ }_{3} \mathrm{H} 1.00 \mathrm{M}$ and diluted to 2.40, 2.20, 2.00, $1.80 \mathrm{~mL}$ with $\mathrm{MeCN}$ and sparged with $\mathrm{O}_{2}$ for 2 minutes. $0.60,0.80,1.00,1.20 \mathrm{~mL}$ of the $\mathrm{Fc}^{*}$ solution was simultaneously sparged with $\mathrm{O}_{2}$. The two solutions were forcefully mixed in a UV cell for 10 seconds. A selection of the time course graphs obtained are presented in Figure S9 (c). 
$\left[\mathrm{O}_{2}\right]$

$10.0 \mu \mathrm{L}$ of the $1.0 \mathrm{mM}$ solution of $[4]\left[\mathrm{BF}_{4}\right]_{2}$ was mixed with $5.0 \mu \mathrm{L} \mathrm{MeSO}{ }_{3} \mathrm{H}$ and diluted to $1.80 \mathrm{~mL}$. $1.20 \mathrm{~mL}$ of the $\mathrm{Fc}^{*}$ solution was taken in a vial. The two solutions were purged with the appropriate gases as described below to result in the desired $\mathrm{O}_{2}$ concentrations. A selection of the time course graphs obtained are presented in Figure $S 9$ (d).

1) Both solutions were saturated with $\mathrm{O}_{2}$.

2) The mixture of the catalyst and $\mathrm{MeSO}_{3} \mathrm{H}$ was saturated with $\mathrm{N}_{2}$ and the solution of $\mathrm{Fc}^{*}$ was saturated with $\mathrm{O}_{2}$.

3) The mixture of the catalyst and $\mathrm{MeSO}_{3} \mathrm{H}$ was saturated with $\mathrm{O}_{2}$ and the solution of $\mathrm{Fc}^{*}$ was saturated with $\mathrm{N}_{2}$.

Background reactions:

$5.0 \mu \mathrm{L} \mathrm{MeSO}{ }_{3} \mathrm{H} 1.00 \mathrm{M}$ was diluted to $1.80 \mathrm{~mL}$ and sparged with $\mathrm{O}_{2}$ for two minutes. $1.20 \mathrm{~mL}$ of the $0.9 \mathrm{mM}$ solution of $\mathrm{Fc}^{*}$ was taken in a vial and sparged with $\mathrm{O}_{2}$ for two minutes. The two solutions were forcefully mixed in a UV cell for 10 seconds. For studying the dependence of the initial reaction rate on $\left[\mathrm{MeSO}_{3} \mathrm{H}\right]$, backgrounds obtained with 2.5, 7.5, and $10.0 \mu \mathrm{L} \mathrm{MeSO}_{3} \mathrm{H}$ were additionally recorded. In all cases, the background absorbance accounted for less than $10 \%$ of the absorbance in the presence of the catalyst.
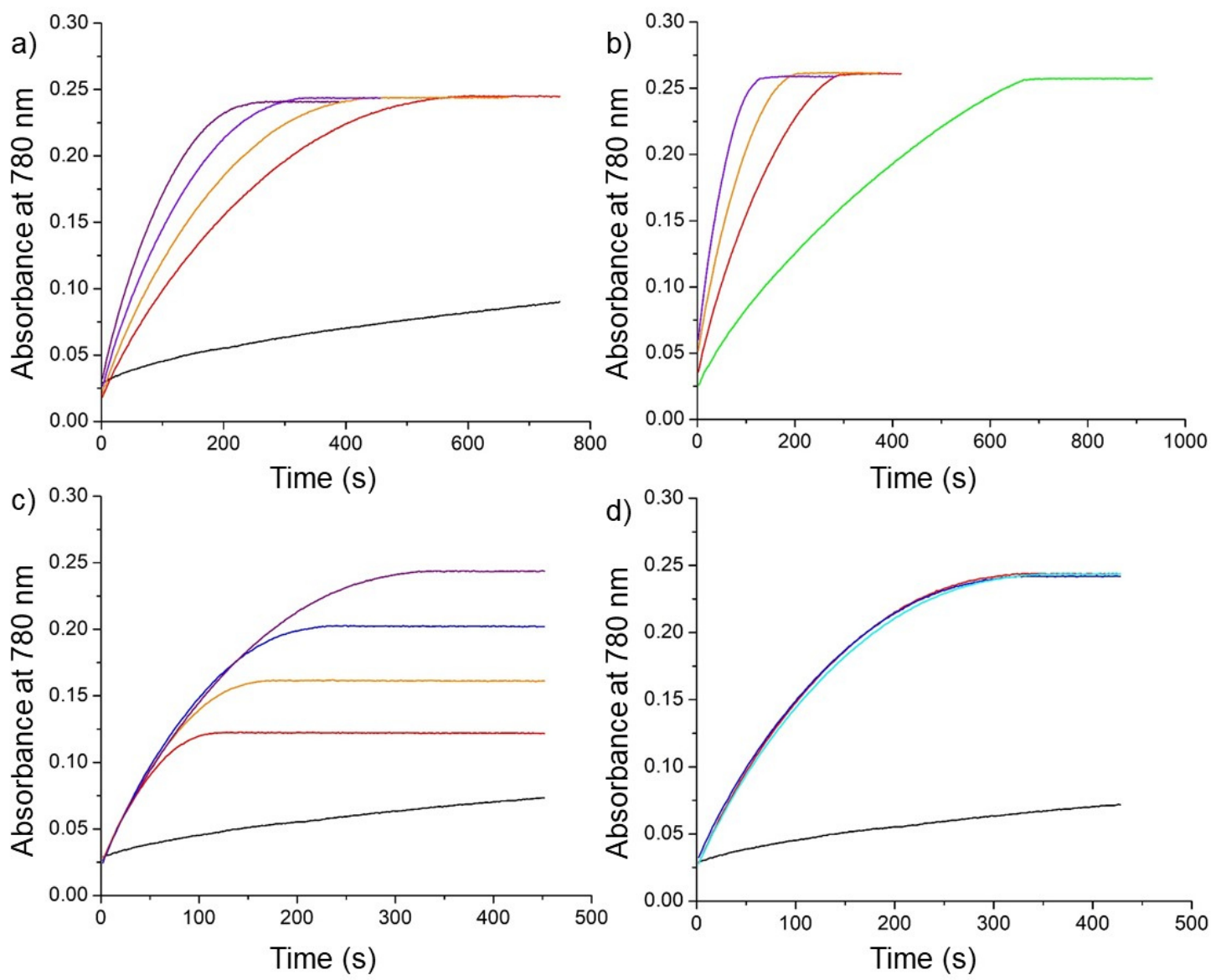
Figure S9: UV-Vis time course graphs obtained by variation of the initial concentration of the reaction components in catalytic $\mathrm{O}_{2}$ reduction by $\mathrm{Fc}^{*}$ in the presence of $\mathrm{MeSO}_{3} \mathrm{H}$ in $\mathrm{O}_{2}$ saturated $\mathrm{MeCN}$ and monitoring the absorbance of $\mathrm{Fc}^{*+}$ at $780 \mathrm{~nm}$. The black traces in the plots show the background uncatalyzed Oxygen reduction. a) variation of the catalyst concentration $[4]\left[\mathrm{BF}_{4}\right]_{2}$ while $\left[\mathrm{MeSO}_{3} \mathrm{H}\right]$ is held constant at $1.66 \mathrm{mM}$ and $\mathrm{Fc}^{*}$ is at $0.36 \mathrm{mM}$. b) variation of $\left[\mathrm{MeSO}_{3} \mathrm{H}\right]$ while catalyst concentration [4] $\left[\mathrm{BF}_{4}\right]_{2}$ is held constant at $3.33 \mu \mathrm{M}$ and $\mathrm{Fc}^{*}$ at 0.36 . c) variation of [Fc*] while catalyst concentration is held constant at $3.33 \mu \mathrm{M}$ and $\left[\mathrm{MeSO}_{3} \mathrm{H}\right]$ is at $1.66 \mathrm{mM}$. d) variation of $\left[\mathrm{O}_{2}\right]$ by mixing different proportions of a $\mathrm{N}_{2}$ - or $\mathrm{O}_{2}$-saturated $\mathrm{MeCN}$ solution containing the catalyst and $\mathrm{MeSO}_{3} \mathrm{H}$, with a solution of $\mathrm{Fc}^{*}$ in $\mathrm{MeCN}$. Bulk initial concentrations: [4] $\left[\mathrm{BF}_{4}\right]_{2} 3.33 \mu \mathrm{M}$, $\left[\mathrm{MeSO}_{3} \mathrm{H}\right] 1.66 \mathrm{mM}, \mathrm{Fc}^{*} 0.36 \mathrm{mM}$.

\section{Analysis of the kinetic data:}

The raw absorbances presented in section VI were analyzed by the initial rate method. The initial reaction rates were calculated for the first $\sim 10 \%$ of the reaction time according to equation 4 ,

ORR rate $=\frac{A_{\sim 10 \%}-A_{0}}{2 \epsilon . b . t_{\sim 10 \%}}$

where the ORR rate is the rate of the consumption of $\mathrm{O}_{2}, A_{\sim 10} \%$ is the absorbance of the solution after $\sim 10 \%$ of the reaction time has passed, $A_{0}$ is the initial absorbance of the solution at $t=0 \mathrm{~s}, \mathrm{~b}$ is the path length of the cell, $\epsilon$ is the molar absorption coefficient of $\mathrm{Fc}^{*+}$, which is evaluated to be $6.6 \times 10^{2} \mathrm{M}^{-1} \cdot \mathrm{cm}^{-1}$ with a similar value reported in the literature, ${ }^{5}$ and the 2 in the denominator accounts for the stoichiometry of the reaction (two moles of $\mathrm{Fc}^{*}$ per one mole of $\mathrm{O}_{2}$ ). The background absorbances are subtracted from the absorbances of the catalytic mixtures, then using eq. (4) ORR rates are plotted against the concentration of each reaction component in Figure S10. 

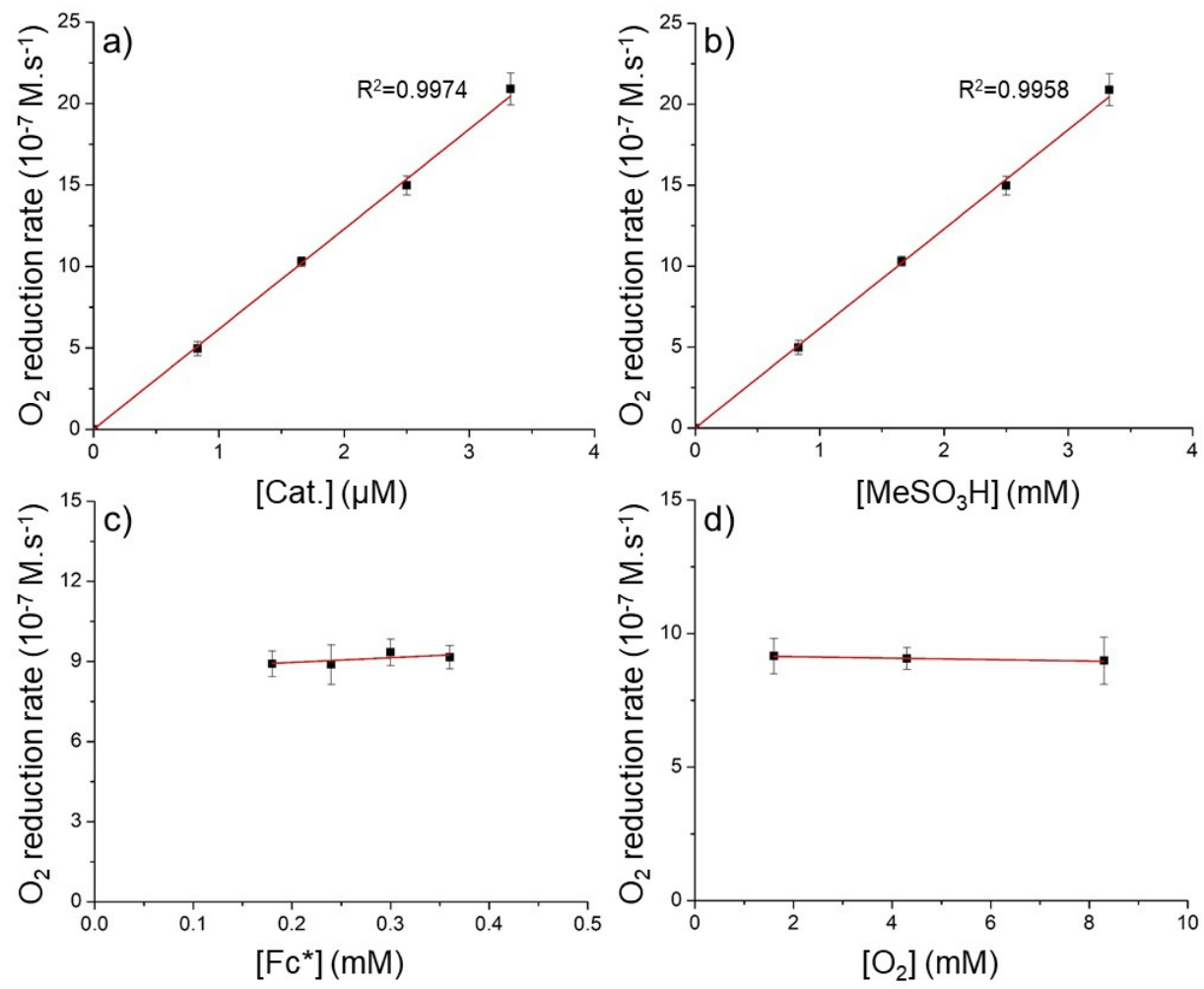

Figure S10: Dependence of the initial rate of $\mathrm{Fc}^{*+}$ formation on the different reaction components in catalytic reduction of $\mathrm{O}_{2}$ by $\mathrm{Fc}^{*}$ in $\mathrm{O}_{2}$-saturated $\mathrm{MeCN}$. (a) Dependence of the initial rate on [4] $\left[\mathrm{BF}_{4}\right]_{2}$ in the presence of $1.66 \mathrm{mM} \mathrm{MeSO}_{3} \mathrm{H}$ and $0.36 \mathrm{mM} \mathrm{Fc}^{*}$. (b) dependence of the initial rate on $\left[\mathrm{MeSO}_{3} \mathrm{H}\right]$ in the presence of $3.33 \mu \mathrm{M}[4]\left[\mathrm{BF}_{4}\right]_{2}$ and $0.36 \mathrm{mM} \mathrm{Fc}^{*}$ (c) dependence of the initial rate on $\left[\mathrm{Fc}^{*}\right]$ in the presence of $3.33 \mu \mathrm{M}[4]\left[\mathrm{BF}_{4}\right]_{2}$ and $1.66 \mathrm{mM} \mathrm{MeSO}_{3} \mathrm{H}$. (d) dependence of the initial rate on $\left[\mathrm{O}_{2}\right]$ in the presence of $3.33 \mu \mathrm{M}[4]\left[\mathrm{BF}_{4}\right]_{2}, 1.66 \mathrm{mM} \mathrm{MeSO}_{3} \mathrm{H}$, and $0.36 \mathrm{mM} \mathrm{Fc}^{*}$.

\section{In situ generation of the bridged peroxides and protonolysis}

Bulk reductions were performed on $3.00 \mathrm{~mL}$ aliquots of $20 \mu \mathrm{M}$ stock solutions of the catalysts in MeCN. In each case the reductant (Zn or Mg, 10 equivalents) was added to the aliquots inside a cuvette in air. The resulting mixture was stirred until no spectral changes were observed. For [1] $\left[\mathrm{BF}_{4}\right],[3]\left[\mathrm{BF}_{4}\right]_{2}$, and $[4]\left[\mathrm{BF}_{4}\right]_{2}$ the reductant was activated Zn powder, however, in the case of [2] $\left[\mathrm{BF}_{4}\right]_{2}, \mathrm{Zn}$ proved to be a very slow reductant, therefore, Mg powder (325 mesh) was used instead. In each case, the resulting solution (assumed to contain 1- $\mathrm{O}_{2}-\mathbf{1}, \mathbf{2}-\mathrm{O}_{2}, \mathbf{3}-\mathrm{O}_{2}$, or 4- $\mathrm{O}_{2}$ ) was filtered through a syringe filter. The filtrate $(2 \mathrm{~mL})$ was treated with $4 \mu \mathrm{L}$ of a freshly prepared 0.1 M solution of $\mathrm{MeSO}_{3} \mathrm{H}$ in MeCN (10 equivalents) and the solution was monitored by UV-Vis spectroscopy. The resulting spectra are shown in Figure S11. 

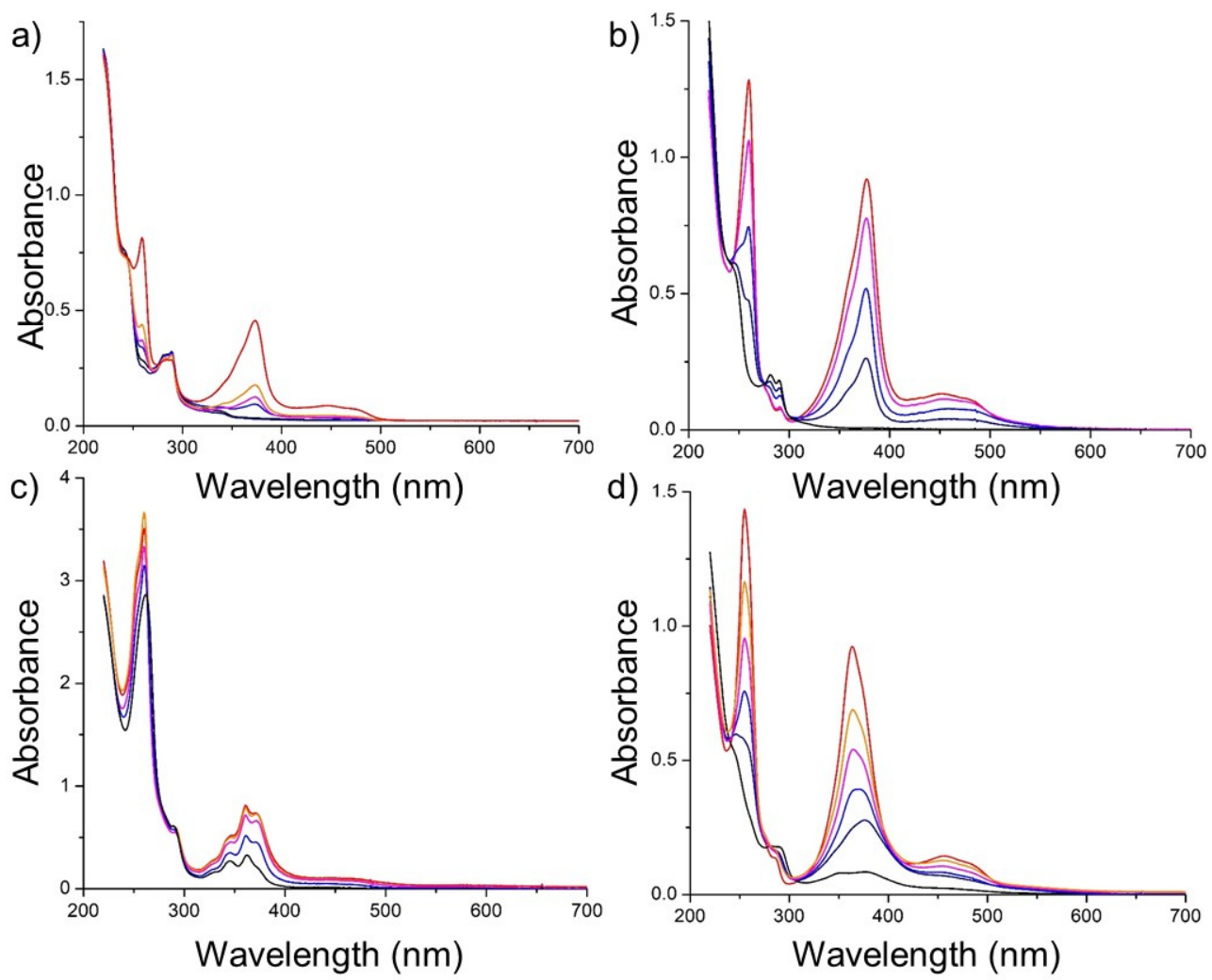

Figure S11: UV-Vis spectra obtained upon addition of 10 equivalents of $\mathrm{MeSO}_{3} \mathrm{H}$ to $20 \mu \mathrm{M}$ solutions of the in situ generated bridged peroxides: a) $1-\mathrm{O}_{2}-\mathbf{1}$, b) $2-\mathrm{O}_{2}$, c) $3-\mathrm{O}_{2}$, or d) $4-\mathrm{O}_{2}$. In all cases the top red trace corresponds to the UV-Vis spectrum of the carbenium salt before treatment with the reductant and the bottom black trace corresponds to the UV-Vis spectrum of the solution obtained after stirring with the reductant, and the navy blue, blue, magenta, and orange traces correspond to UV-Vis spectra recorded at different time intervals after addition of $\mathrm{MeSO}_{3} \mathrm{H}$. a) Protonolysis of 1$\mathrm{O}_{2}-1$ : spectra recorded at 480,1800, 2700, and 3600 seconds b) Protonolysis of 2- $\mathrm{O}_{2}$ : spectra recorded at 900, 1800, 2700, and 3600 seconds c) Protonolysis of 3- $\mathrm{O}_{2}$ : spectra recorded at 9, 15, and 18 seconds d) Protonolysis of 4- $\mathrm{O}_{2}$ : spectra recorded at 2, 4, 6, and 8 seconds.

\section{Cyclic Voltammetry}

\section{A. General remarks}

A three-electrode setup was employed for the CV experiments, consisting of a glassy carbon working electrode, a $\mathrm{Pt}$ wire counter electrode, and an aqueous $\mathrm{Ag} / \mathrm{AgCl}$ reference electrode. [TBA] $\left[\mathrm{PF}_{6}\right]$ was used as the supporting electrolyte in $0.1 \mathrm{M}$ concentration and acetonitrile was used as the solvent. The electrodes were polished for 5 minutes prior to use. All potentials were internally referenced to Ferrocene and reported with respect to the $\mathrm{Fc}^{+/ 0}$ couple.

\section{B. Cyclic voltammograms of $[4]\left[\mathrm{BF}_{4}\right]_{2}$}

1) A Cyclic Voltammogram of [4][BF $]_{2}$ in the presence of $\mathrm{O}_{2}$ and $\mathrm{N}_{2}$ at a scan rate of $500 \mathrm{mV} \cdot \mathrm{s}^{-1}$ is shown in Figure S12 (a) and (b) respectively. The oxidation event at $1.5 \mathrm{~V} \mathrm{vs} \mathrm{Fc}^{+/ 0}$ is only 
observable at scan rates higher than $300 \mathrm{mV} . \mathrm{s}^{-1}$ and only when potential is swept past the second wave as evident in Figure S12 (c) and (d). Addition of 2 equivalents of cobaltocene under an atmosphere of $\mathrm{N}_{2}$, followed by introduction of oxygen results in complete consumption of the dication (Figure S12 (f)) and much larger currents at $1.5 \mathrm{~V}$ (Figure S12 (e) and (f)), consistent with in-situ formation of 4- $\mathrm{O}_{2}$.
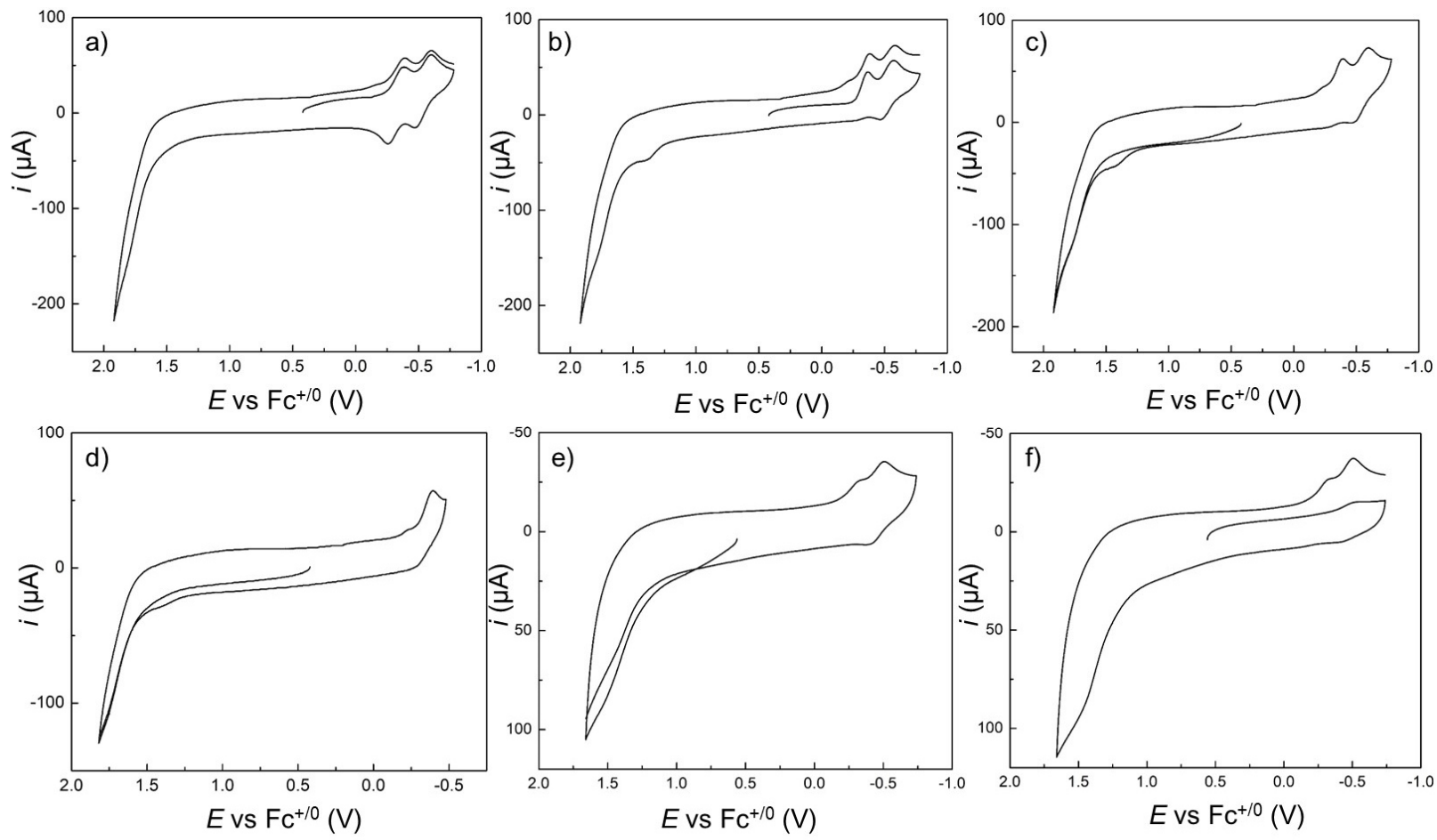

Figure S12: Cyclic Voltammograms of $1.0 \mathrm{mM}$ [4] $\left[\mathrm{BF}_{4}\right]_{2}$ in $0.1 \mathrm{M}\left[{ }^{n} \mathrm{Bu}_{4} \mathrm{~N}\right]\left[\mathrm{PF}_{6}\right]$ in $\mathrm{MeCN}$ at a scan

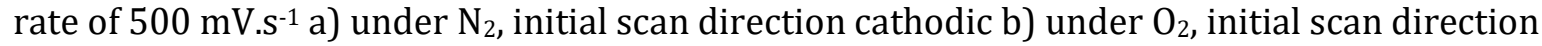
cathodic c) under $\mathrm{O}_{2}$, initial scan direction anodic. The oxidation event at $1.5 \mathrm{~V}$ is observable only after a cathodic scan past the second wave. d) under $\mathrm{O}_{2}$, initial scan direction anodic. e) under $\mathrm{O}_{2}$ after addition of 2 equivalents of $\mathrm{Cp}_{2} \mathrm{Co}$ under $\mathrm{N}_{2}$, initial scan direction anodic. The oxidation wave at $1.5 \mathrm{~V}$ is greatly intensified and it is observable in the initial anodic scan. f) under $\mathrm{O}_{2}$ after addition of 2 equivalents of $\mathrm{Cp}_{2} \mathrm{Co}$ under $\mathrm{N}_{2}$, initial scan direction cathodic. The First forward scan shows complete consumption of the dication because of formation of the bridged peroxide species 4- $\mathrm{O}_{2}$. 
2) Cyclic Voltammogram of $[3]\left[\mathrm{BF}_{4}\right]_{2}$ :

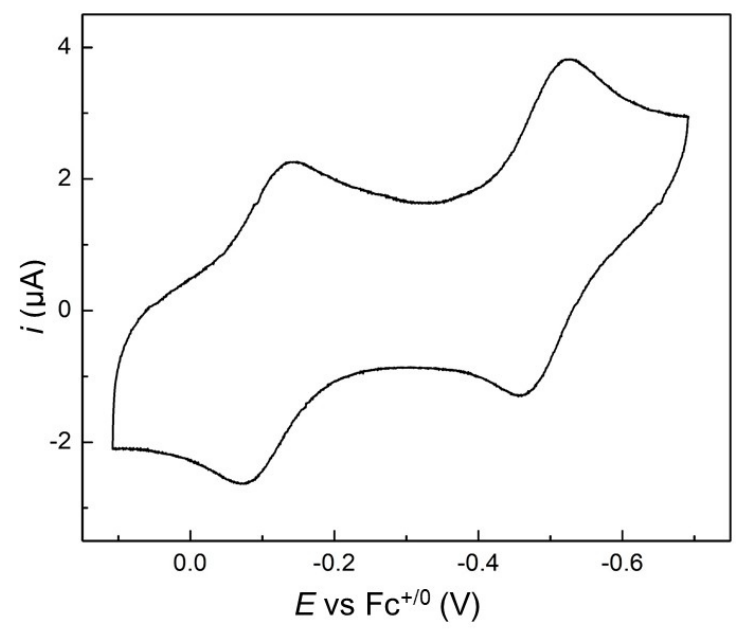

Figure S13: Cyclic Voltammogram of $0.2 \mathrm{mM}[3]\left[\mathrm{BF}_{4}\right]_{2}$ in $0.1 \mathrm{M}\left[{ }^{n} \mathrm{Bu}_{4} \mathrm{~N}\right]\left[\mathrm{PF}_{6}\right]$ in $\mathrm{CH}_{2} \mathrm{Cl}_{2}$ at a scan rate of $100 \mathrm{mV} \cdot \mathrm{s}^{-1}$ recorded under $\mathrm{N}_{2}$. $\mathrm{E}_{1 / 2}(1)=-0.11 \mathrm{~V}^{2}$ and $\mathrm{E}_{1 / 2}(2)=-0.49 \mathrm{~V} \mathrm{vs} \mathrm{Fc}^{+/ 0}$.

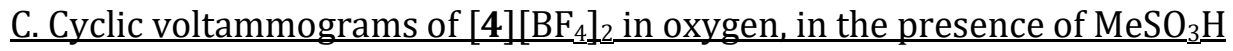

Cyclic Voltammograms of $1.0 \mathrm{mM}[4]\left[\mathrm{BF}_{4}\right]_{2}$ in MeCN were also recorded in the presence of $0.1 \mathrm{M}$ $[\mathrm{TBA}]\left[\mathrm{PF}_{6}\right]$ and different concentrations of $\mathrm{MeSO}_{3} \mathrm{H}$ at a scan rate of $50 \mathrm{mV} \cdot \mathrm{s}^{-1}$. These voltammograms along with their respective background voltammograms recorded under identical conditions are presented in Figure S14.
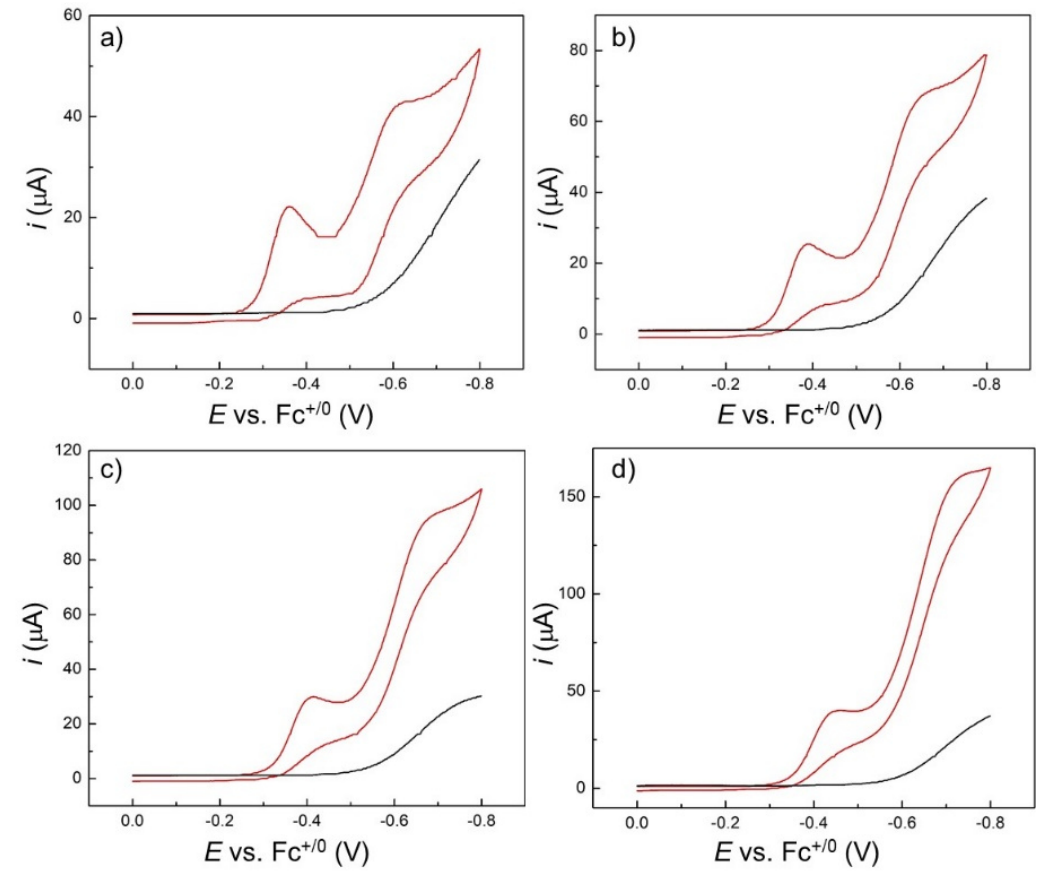

Figure S14: CVs recorded using a $1.0 \mathrm{mM}$ solution of [4] $\left[\mathrm{BF}_{4}\right]_{2}$ in $0.1 \mathrm{M}[\mathrm{TBA}]\left[\mathrm{PF}_{6}\right]$ in $\mathrm{MeCN}$ in the presence of different amounts of $\mathrm{MeSO}_{3} \mathrm{H}$ (a) 10 equivalents, b) 25 equivalents, c) 50 equivalents 
d)100 equivalents) at $50 \mathrm{mV} . \mathrm{s}^{-1}$. The red traces show the catalytic currents and the black traces show the background currents.

\section{Open Circuit Potential measurement and overpotential analysis}

A four-electrode setup was employed for the OCP measurement, which consisted of two glassy carbon working electrodes, a Pt wire counter electrode, and a $\mathrm{Ag} / \mathrm{AgCl}$ reference electrode. The reduction potential of $\mathrm{O}_{2} / \mathrm{H}_{2} \mathrm{O}_{2}$ in organic solutions can be estimated following the protocol developed by Mayer et al.11 This method relies on a thermochemical cycle that involves terms that are either known or can be measured as evident in the following:

i) $\mathrm{O}_{2(\mathrm{~g})}+2 \mathrm{H}^{+}{ }_{(\mathrm{aq})}+2 \mathrm{e}_{(\mathrm{SHE})}^{-} \rightarrow \mathrm{H}_{2} \mathrm{O}_{2(\mathrm{aq})}$

$\mathrm{E}=0.68 \mathrm{~V}$ vs SHE

ii) $\mathrm{H}_{2(\mathrm{~g})} \rightarrow 2 \mathrm{H}^{+}{ }_{(\mathrm{aq})}+2 \mathrm{e}^{-}(\mathrm{SHE})$

$\mathrm{E}=0 \mathrm{~V}$ vs SHE

iii) $\left.2 \mathrm{H}^{+}{ }_{(\mathrm{MeCN})}+2 \mathrm{e}^{-}{ }_{(\mathrm{Fc}+} / 0\right) \rightarrow \mathrm{H}_{2(\mathrm{~g})}$

E obtained from OCP measurement

iv) $\mathrm{H}_{2} \mathrm{O}_{2(\text { aq) }} \rightarrow \mathrm{H}_{2} \mathrm{O}_{2(\mathrm{MeCN})}$

$\Delta \mathrm{G}_{\text {transfer }}$

v) $\mathrm{O}_{2(\mathrm{~g})}+2 \mathrm{H}^{+}{ }_{(\mathrm{MeCN})}+2 \mathrm{e}^{-}{ }_{(\mathrm{Fc}+/ 0)} \rightarrow \mathrm{H}_{2} \mathrm{O}_{2(\mathrm{MeCN})}$

$\mathrm{E}\left(\mathrm{O}_{2} / \mathrm{H}_{2} \mathrm{O}_{2(\mathrm{MeCN})}\right)$

The potential associated with (iii) can be directly determined by measuring the Open Circuit Potential of a solution of $\mathrm{MeSO}_{3} \mathrm{H}$ in $\mathrm{MeCN}$ buffered with $\mathrm{Na} \mathrm{MeSO}_{3}$, under 1 atm $\mathrm{H}_{2}$, employing a Pt electrode. This potential may then be internally referenced to $\mathrm{Fc}^{+/ 0}$ by adding $\mathrm{Fc}$ and running a CV using the second working electrode. The standard free energy to transfer $\mathrm{H}_{2} \mathrm{O}$ from water to MeCN has been measured to be $-0.43 \mathrm{kCal} / \mathrm{mol}$, which has a negligible effect on the reduction potential of $\mathrm{O}_{2} / \mathrm{H}_{2} \mathrm{O}^{11}$. Moreover, the correction to the reduction potential of $\mathrm{O}_{2} / \mathrm{H}_{2} \mathrm{O}_{2}$ in $\mathrm{MeOH}$ due to the free energy to transfer $\mathrm{H}_{2} \mathrm{O}_{2}$ from water to $\mathrm{MeOH}$ has previously been approximated to be zero. ${ }^{5}$ Given that, it is reasonable to approximate that the free energy associated with (iv) can be assumed to be negligible. Therefore, addition of the potentials associated with (i) and (iii) will give an estimate of $\mathrm{E}\left(\mathrm{O}_{2} / \mathrm{H}_{2} \mathrm{O}_{2(\mathrm{MeCN})}\right)$.

The conditions employed for the OCP measurement consist of $1.66 \mathrm{mM} \mathrm{MeSO}{ }_{3} \mathrm{H}, 1.66 \mathrm{mM} \mathrm{NaMeSO}_{3}$, $1 \mathrm{~atm} \mathrm{H}_{2}$ in $\mathrm{MeCN}$ (local pressure $762 \mathrm{mmHg}$, correction to potential < $1 \mathrm{mV}$ ). The measured value of $-0.81 \mathrm{~V}$ vs Fc $\mathrm{Fc}^{+/ 0}$ shown in Figure S15 corresponds to a reduction potential of $-0.13 \mathrm{vs} \mathrm{Fc}^{+/ 0}$ for (v). This value must then undergo a Nernstian correction to $-0.04 \mathrm{~V}$ to account for the non-standard state $\mathrm{H}_{2} \mathrm{O}_{2}$ concentration of $1.0 \mathrm{mM}$ in the reference solution, according to the Nernst equation (5). 


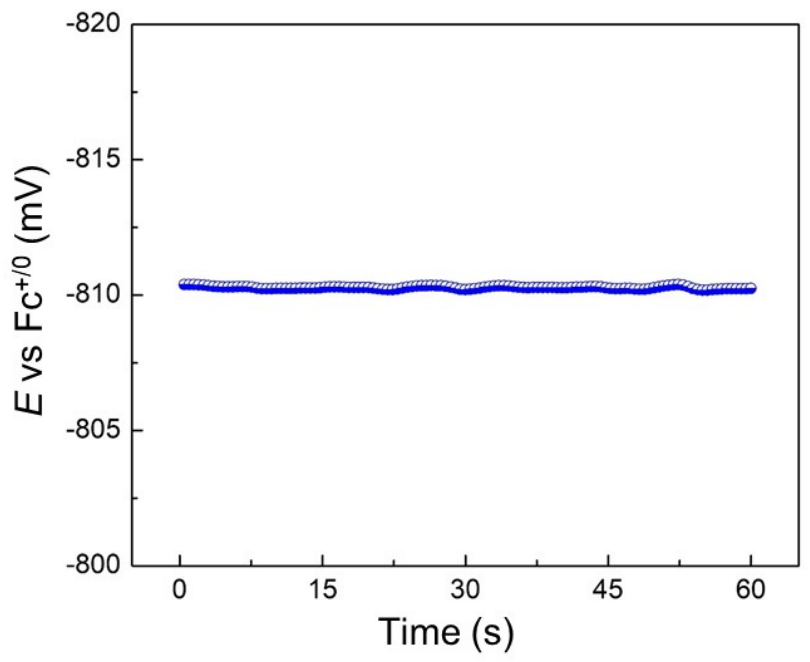

Figure S15: Open Circuit Potential vs time in $1.66 \mathrm{mM} \mathrm{MeSO}_{3} \mathrm{H}, 1.66 \mathrm{mM} \mathrm{Na} \mathrm{MeSO}{ }_{3}, 1 \mathrm{~atm} \mathrm{H}_{2}$, in $\mathrm{MeCN}$ displays a stable potential. The potential was averaged over 60 seconds to give a value of $0.81 \mathrm{~V}$ vs $\mathrm{Fc}^{+} / 0$.

$E_{02 / \mathrm{H} 202(\mathrm{MeCN})}=-0.13 \mathrm{~V}-0.030 \mathrm{~V} \times \log \left(\left[\mathrm{H}_{2} \mathrm{O}_{2}\right]_{1 \mathrm{M}} /\left[\mathrm{H}_{2} \mathrm{O}_{2}\right]_{1 \mathrm{mM}}\right)=-0.04 \mathrm{~V}$

Reaction overpotentials are equal to the difference between the $\mathrm{E}_{\frac{1}{2} / 2}$ of the catalysts and $-0.04 \mathrm{~V}$.

\section{Spectroelectrochemistry}

Spectroelectrochemical studies were conducted in air using a Pt honeycomb electrode from Pine Research ( $\mathrm{l}=1.4 \mathrm{~mm}$ as established by calibration), a Pt wire counter electrode and a $\mathrm{Ag} / \mathrm{AgCl}$ low profile reference electrode. The electrodes were immersed in a $1.05 \times 10^{-4} \mathrm{M}$ solution of $[4]\left[\mathrm{BF}_{4}\right]_{2}$ with $0.1 \mathrm{M}[\mathrm{TBA}]\left[\mathrm{PF}_{6}\right]$ as the supporting electrolyte in MeCN. Absorption spectra were measured against a blank solution containing the same concentration of the supporting electrolyte in MeCN. The potential was kept at $-0.5 \mathrm{~V}$ vs. $\mathrm{Fc}^{+/ 0}$ for 25 seconds during which time conversion of [4] ${ }^{2+}$ into 4- $\mathrm{O}_{2}$ took place. The potential was then immediately switched to $1.5 \mathrm{~V} \mathrm{vs} \mathrm{Fc}^{+} / 0$ and kept constant for 25 seconds during which time oxidation of 4- $\mathrm{O}_{2}$ occurred. The UV-vis spectra were collected on a Hewlett-Packard 8453 spectrophotometer at 3 seconds intervals using an automated acquisition mode available in the instrument software.

\section{Computational Details}

All computations were carried out with the Gaussian 16 program using the gradient-corrected Becke exchange functional and the Lee-Yang-Parr correlation functional (B3LYP). Geometry optimizations were carried out using the basis set $6-31+\mathrm{g}(\mathrm{d})$ for all atoms. Frequency calculations, which were carried out on the optimized structures of the compounds, confirmed the absence of any imaginary frequencies. To calculate the peroxide ion affinities of the dicarbeniums, the optimized geometries of the dications $\left([2]^{2+},[3]^{2+},[4]^{2+}\right)$ and their respective peroxides $\left(2-\mathrm{O}_{2}, \mathbf{3}-\mathrm{O}_{2}\right.$, 4- $\mathrm{O}_{2}$ ) were subjected to single-point energy calculations using the B3LYP functional and the 6 $311+\mathrm{g}(2 \mathrm{~d}, \mathrm{p})$ basis set for all atoms. The peroxide ion affinities (PIA) were calculated as shown in equation 6 . The reaction enthalpies $\Delta H$ were derived from the energy of each molecule (from the 
single-point calculation) corrected by the "thermal correction to enthalpy" terms obtained from the frequency calculations (Table S1).

Dicarbenium $+\mathrm{O}_{2}{ }^{2-} \stackrel{\Delta H}{\longrightarrow}$ Dicarbenium peroxide $\quad$ with $\mathrm{PIA}=-\Delta H$

Table S1. Computed energies in Hartrees

\begin{tabular}{|l|c|c|c|}
\hline \multicolumn{1}{|c|}{ Species } & SCF Energy & Thermal correction to enthalpy & Enthalpy \\
\hline$[\mathbf{2}]^{2+}$ & -1687.702653 & 0.541636 & -1687.161017 \\
\hline $\mathbf{2}-\mathrm{O}_{2}$ & -1839.004102 & 0.571219 & -1838.432883 \\
\hline$[\mathbf{3}]^{2+}$ & -1611.582645 & 0.512813 & -1611.069832 \\
\hline $\mathbf{3}-\mathrm{O}_{2}$ & -1762.512323 & 0.541281 & -1761.971042 \\
\hline$[\mathbf{4}]^{2+}$ & -1804.88012 & 0.608011 & -1804.272109 \\
\hline $\mathbf{4}-\mathrm{O}_{2}$ & -1955.768999 & 0.64002 & -1955.128979 \\
\hline Peroxide & -150.0936322 & 0.005028 & -150.0886042 \\
\hline
\end{tabular}

The PIA values calculated for $[2]^{2+},[3]^{2+}$, and $[4]^{2+}$ are $742.5,509.9$, and 482.1 kcal.mol $^{-1}$ respectively. 
Optimized geometry of $[2]^{2+}$ :

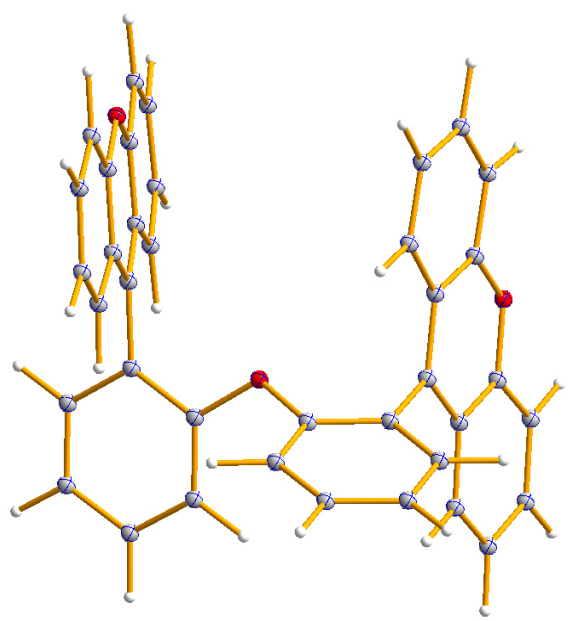

Cartesian coordinates of the optimized structure of $[2]^{2+}$ :

\begin{tabular}{|c|c|c|c|}
\hline Atom Type & $\mathrm{X}$ & $\mathrm{Y}$ & $\mathrm{Z}$ \\
\hline $\mathrm{C}$ & 0.230443 & -2.83195 & 3.364571 \\
\hline $\mathrm{C}$ & -0.28677 & -2.4754 & 2.118294 \\
\hline $\mathrm{C}$ & 0.4338 & -1.61847 & 1.282716 \\
\hline $\mathrm{C}$ & 1.673876 & -1.09604 & 1.697397 \\
\hline $\mathrm{C}$ & 2.163479 & -1.44799 & 2.969782 \\
\hline $\mathrm{C}$ & 1.45773 & -2.3209 & 3.794674 \\
\hline $\mathrm{H}$ & -0.33457 & -3.505 & 4.002738 \\
\hline $\mathrm{H}$ & -1.24661 & -2.86446 & 1.796098 \\
\hline $\mathrm{H}$ & 3.121823 & -1.05237 & 3.295373 \\
\hline $\mathrm{H}$ & 1.862548 & -2.59846 & 4.762713 \\
\hline 0 & -0.06808 & -1.16497 & 0.06864 \\
\hline $\mathrm{C}$ & -0.95098 & -1.96045 & -0.65739 \\
\hline $\mathrm{C}$ & -2.15932 & -1.38977 & -1.09284 \\
\hline $\mathrm{C}$ & -0.62611 & -3.27601 & -0.99608 \\
\hline $\mathrm{C}$ & -3.03267 & -2.17182 & -1.87287 \\
\hline $\mathrm{C}$ & -1.50097 & -4.03436 & -1.77387 \\
\hline $\mathrm{H}$ & 0.305174 & -3.70583 & -0.64197 \\
\hline $\mathrm{C}$ & -2.70603 & -3.48176 & -2.21752 \\
\hline $\mathrm{H}$ & -3.96727 & -1.73844 & -2.21886 \\
\hline $\mathrm{H}$ & -1.23911 & -5.05562 & -2.03417 \\
\hline $\mathrm{H}$ & -3.38837 & -4.06629 & -2.82667 \\
\hline $\mathrm{C}$ & 2.492989 & -0.19876 & 0.839381 \\
\hline $\mathrm{C}$ & 2.662287 & 1.167927 & 1.188945 \\
\hline $\mathrm{C}$ & 3.187275 & -0.70325 & -0.29226 \\
\hline $\mathrm{C}$ & 2.032046 & 1.787838 & 2.311064 \\
\hline $\mathrm{C}$ & 3.504686 & 1.987399 & 0.379537 \\
\hline $\mathrm{C}$ & 4.000303 & 0.185523 & -1.05591 \\
\hline $\mathrm{C}$ & 3.173463 & -2.07441 & -0.68694 \\
\hline $\mathrm{C}$ & 2.262372 & 3.114129 & 2.599811 \\
\hline
\end{tabular}

\begin{tabular}{|c|c|c|c|}
\hline $\mathrm{H}$ & 1.37564 & 1.194369 & 2.937157 \\
\hline $\mathrm{C}$ & 3.736865 & 3.336054 & 0.668585 \\
\hline $\mathrm{C}$ & 4.72761 & -0.23914 & -2.17278 \\
\hline $\mathrm{H}$ & 2.607435 & -2.78131 & -0.09142 \\
\hline $\mathrm{C}$ & 3.894693 & -2.4983 & -1.77981 \\
\hline $\mathrm{C}$ & 3.121515 & 3.887929 & 1.780104 \\
\hline $\mathrm{H}$ & 1.788782 & 3.57332 & 3.461795 \\
\hline $\mathrm{H}$ & 4.39719 & 3.91283 & 0.029189 \\
\hline $\mathrm{C}$ & 4.667403 & -1.5761 & -2.52945 \\
\hline $\mathrm{H}$ & 5.33411 & 0.476214 & -2.71863 \\
\hline $\mathrm{H}$ & 3.890142 & -3.54591 & -2.06378 \\
\hline $\mathrm{H}$ & 3.301331 & 4.930498 & 2.025936 \\
\hline $\mathrm{H}$ & 5.23753 & -1.92581 & -3.38518 \\
\hline $\mathrm{C}$ & -2.54758 & 0.01208 & -0.77185 \\
\hline $\mathrm{C}$ & -3.56773 & 0.272448 & 0.178215 \\
\hline $\mathrm{C}$ & -1.96307 & 1.103881 & -1.46582 \\
\hline $\mathrm{C}$ & -4.23913 & -0.74256 & 0.927128 \\
\hline $\mathrm{C}$ & -3.95658 & 1.625836 & 0.417882 \\
\hline $\mathrm{C}$ & -2.41575 & 2.424584 & -1.17637 \\
\hline $\mathrm{C}$ & -0.98099 & 0.957696 & -2.49081 \\
\hline $\mathrm{C}$ & -5.22431 & -0.411 & 1.828889 \\
\hline $\mathrm{H}$ & -3.96543 & -1.77918 & 0.767262 \\
\hline $\mathrm{C}$ & -4.95416 & 1.965021 & 1.336691 \\
\hline $\mathrm{C}$ & -1.91911 & 3.548246 & -1.84618 \\
\hline $\mathrm{H}$ & -0.64006 & -0.03857 & -2.74965 \\
\hline $\mathrm{C}$ & -0.49654 & 2.06063 & -3.15703 \\
\hline $\mathrm{C}$ & -5.58338 & 0.945509 & 2.032327 \\
\hline $\mathrm{H}$ & -5.734 & -1.18852 & 2.38895 \\
\hline $\mathrm{H}$ & -5.21869 & 3.007828 & 1.478027 \\
\hline $\mathrm{C}$ & -0.96556 & 3.358599 & -2.83224 \\
\hline $\mathrm{H}$ & -2.30286 & 4.531867 & -1.59575 \\
\hline $\mathrm{H}$ & 0.234564 & 1.939957 & -3.9503 \\
\hline $\mathrm{H}$ & -6.36594 & 1.190864 & 2.744383 \\
\hline $\mathrm{H}$ & -0.58368 & 4.218011 & -3.37573 \\
\hline 0 & 4.118636 & 1.486029 & -0.71269 \\
\hline 0 & -3.36886 & 2.643022 & -0.24662 \\
\hline
\end{tabular}


Optimized geometry of $2-\mathrm{O}_{2}$ :

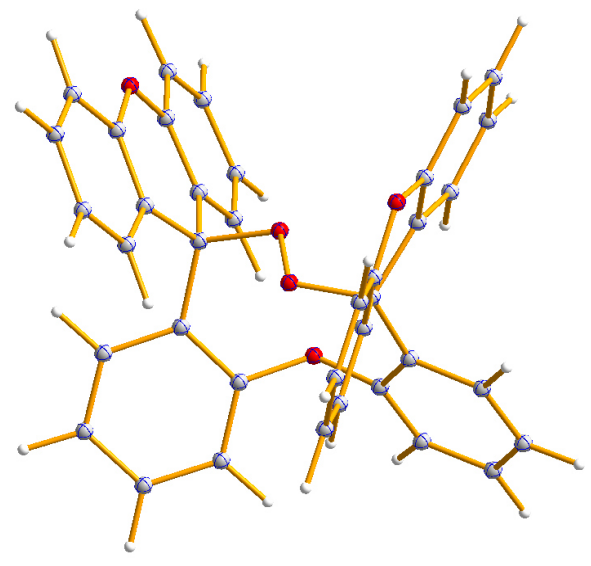

Cartesian coordinates of the optimized structure of $\mathbf{2 -}$ $\mathrm{O}_{2}$ :

\begin{tabular}{|c|r|r|r|}
\hline Atom Type & \multicolumn{1}{|c|}{$\mathrm{X}$} & \multicolumn{1}{c|}{$\mathrm{Y}$} & $\mathrm{Z}$ \\
\hline C & 3.048517 & 4.06176 & 1.120431 \\
\hline C & 1.722236 & 3.83594 & 0.764971 \\
\hline C & 1.264982 & 2.540722 & 0.481627 \\
\hline C & 2.126002 & 1.43372 & 0.566839 \\
\hline C & 3.45868 & 1.692466 & 0.938038 \\
\hline C & 3.92464 & 2.976269 & 1.207678 \\
\hline H & 3.390471 & 5.070232 & 1.337501 \\
\hline H & 1.006017 & 4.651411 & 0.722675 \\
\hline H & 4.144885 & 0.853986 & 1.020222 \\
\hline H & 4.962777 & 3.125465 & 1.491619 \\
\hline O & -0.09379 & 2.394436 & 0.267615 \\
\hline C & -0.65732 & 2.338413 & -0.9962 \\
\hline C & -1.58776 & 1.318413 & -1.26121 \\
\hline C & -0.39741 & 3.346701 & -1.92897 \\
\hline C & -2.3154 & 1.410461 & -2.45675 \\
\hline C & -1.10738 & 3.388831 & -3.12846 \\
\hline H & 0.345079 & 4.104404 & -1.69803 \\
\hline C & -2.09147 & 2.431335 & -3.38139 \\
\hline H & -3.05922 & 0.651128 & -2.67728 \\
\hline H & -0.90653 & 4.17892 & -3.84747 \\
\hline H & -2.67327 & 2.466782 & -4.29831 \\
\hline C & 1.757567 & -0.04593 & 0.320766 \\
\hline C & 2.697723 & -0.6749 & -0.70649 \\
\hline C & 1.777548 & -0.84446 & 1.617902 \\
\hline C & 3.087055 & 0.014891 & -1.86557 \\
\hline C & 3.086982 & -2.01298 & -0.57639 \\
\hline C & 2.226725 & -2.16934 & 1.622783 \\
\hline C & 1.283336 & -0.31805 & 2.821176 \\
\hline C & 3.842765 & -0.60459 & -2.85715 \\
\hline H & 2.78332 & 1.050545 & -1.98526 \\
\hline & & & \\
\hline
\end{tabular}

\begin{tabular}{|r|r|r|r|}
\hline C & 3.85199 & -2.64847 & -1.56156 \\
\hline C & 2.176242 & -2.95823 & 2.7769 \\
\hline H & 0.925424 & 0.706317 & 2.836588 \\
\hline C & 1.224851 & -1.08813 & 3.979199 \\
\hline C & 4.225057 & -1.94388 & -2.70123 \\
\hline H & 4.129621 & -0.05111 & -3.74676 \\
\hline H & 4.138635 & -3.68494 & -1.41125 \\
\hline C & 1.66955 & -2.41636 & 3.953381 \\
\hline H & 2.541958 & -3.97949 & 2.728474 \\
\hline H & 0.827168 & -0.66006 & 4.894931 \\
\hline H & 4.81797 & -2.43693 & -3.46718 \\
\hline H & 1.627481 & -3.02653 & 4.851821 \\
\hline C & -1.81746 & 0.125386 & -0.31107 \\
\hline C & -2.11861 & -1.16874 & -1.06945 \\
\hline C & -2.89979 & 0.406129 & 0.727457 \\
\hline C & -1.37853 & -1.55582 & -2.20171 \\
\hline C & -3.07087 & -2.07446 & -0.58901 \\
\hline C & -3.82602 & -0.58104 & 1.085461 \\
\hline C & -2.97033 & 1.638189 & 1.401949 \\
\hline C & -1.58005 & -2.78543 & -2.82125 \\
\hline H & -0.62682 & -0.8791 & -2.59083 \\
\hline C & -3.29022 & -3.31468 & -1.20155 \\
\hline C & -4.7945 & -0.35684 & 2.072653 \\
\hline H & -2.24996 & 2.410112 & 1.159437 \\
\hline C & -3.92514 & 1.875254 & 2.385284 \\
\hline C & -2.54184 & -3.67062 & -2.31666 \\
\hline H & -0.98603 & -3.05605 & -3.6897 \\
\hline H & -4.04761 & -3.97265 & -0.78617 \\
\hline H & -4.84173 & 0.869862 & 2.722548 \\
\hline H & -5.49215 & -1.15554 & 2.305885 \\
\hline H & -3.95394 & 2.836544 & 2.890621 \\
\hline-2.70821 & -4.63316 & -2.79331 \\
\hline-5.59256 & 1.045025 & 3.488679 \\
\hline 2.75868 & -2.77812 & 0.51066 \\
\hline-3.86409 & -1.81799 & 0.501334 \\
\hline O & & & \\
\hline
\end{tabular}


Optimized geometry of $[3]^{2+}$ :

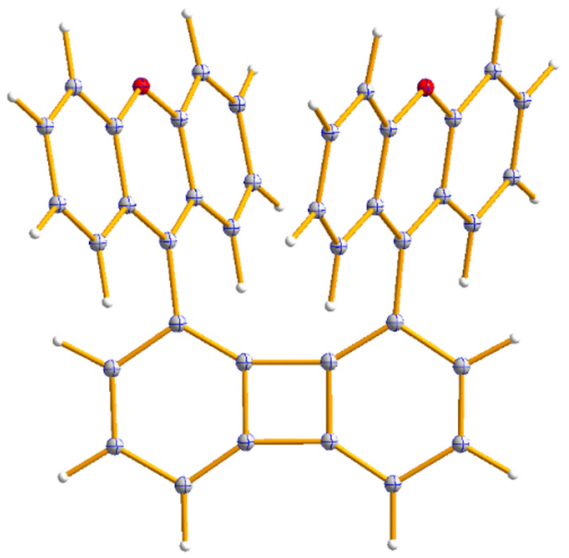

Cartesian coordinates of the optimized structure of $[3]^{2+}$ :

\begin{tabular}{|c|l|l|l|}
\hline Atom Type & \multicolumn{1}{|c|}{$\mathrm{X}$} & \multicolumn{1}{c|}{$\mathrm{Y}$} & $\mathrm{Z}$ \\
\hline C & -1.7692 & 4.552888 & 0.648766 \\
\hline C & -0.70221 & 3.780605 & 0.261902 \\
\hline C & -0.70851 & 2.356245 & 0.283063 \\
\hline C & -1.82378 & 1.652907 & 0.715649 \\
\hline C & -2.94762 & 2.453526 & 1.106768 \\
\hline C & -2.9167 & 3.84052 & 1.082434 \\
\hline H & -1.75612 & 5.638181 & 0.635411 \\
\hline H & -3.84098 & 1.953716 & 1.470037 \\
\hline H & -3.79362 & 4.390327 & 1.411349 \\
\hline C & 0.708495 & 2.356254 & -0.28336 \\
\hline C & 1.82387 & 1.652884 & -0.71565 \\
\hline C & 0.702204 & 3.780599 & -0.26217 \\
\hline C & 2.947812 & 2.453501 & -1.10648 \\
\hline C & 1.769326 & 4.552873 & -0.64871 \\
\hline C & 2.916903 & 3.840498 & -1.08215 \\
\hline H & 3.841244 & 1.953699 & -1.4696 \\
\hline H & 1.756271 & 5.638166 & -0.63531 \\
\hline H & 3.793896 & 4.3903 & -1.41087 \\
\hline C & -1.94062 & 0.182782 & 0.860431 \\
\hline C & -1.16539 & -0.51503 & 1.829097 \\
\hline C & -2.90588 & -0.54108 & 0.108481 \\
\hline C & -0.23317 & 0.115361 & 2.708244 \\
\hline C & -1.38282 & -1.91382 & 2.005328 \\
\hline C & -3.06003 & -1.93966 & 0.348662 \\
\hline C & -3.74239 & 0.044294 & -0.89138 \\
\hline C & 0.435368 & -0.61711 & 3.663917 \\
\hline H & -0.08234 & 1.18605 & 2.632558 \\
\hline C & -0.69821 & -2.6618 & 2.969344 \\
\hline C & -4.0018 & -2.71687 & -0.33259 \\
\hline H & -3.6373 & 1.100205 & -1.11254 \\
\hline & & & \\
\hline
\end{tabular}

\begin{tabular}{|l|l|l|l|}
\hline C & -4.67309 & -0.71802 & -1.56077 \\
\hline C & 0.205505 & -2.00941 & 3.791839 \\
\hline H & 1.124534 & -0.12397 & 4.342258 \\
\hline H & -0.90869 & -3.72169 & 3.069892 \\
\hline C & -4.80803 & -2.09989 & -1.27541 \\
\hline H & -4.0898 & -3.77352 & -0.10162 \\
\hline H & -5.31164 & -0.26163 & -2.31057 \\
\hline H & 0.727222 & -2.57109 & 4.561371 \\
\hline H & -5.55406 & -2.68603 & -1.80427 \\
\hline C & 1.940674 & 0.182779 & -0.86046 \\
\hline C & 1.165397 & -0.51501 & -1.82914 \\
\hline C & 2.905878 & -0.54115 & -0.10849 \\
\hline C & 0.233185 & 0.115406 & -2.70828 \\
\hline C & 1.382749 & -1.91381 & -2.00535 \\
\hline C & 3.060001 & -1.93972 & -0.34872 \\
\hline C & 3.742363 & 0.044152 & 0.891423 \\
\hline C & -0.43541 & -0.61705 & -3.66392 \\
\hline H & 0.082417 & 1.186105 & -2.63264 \\
\hline C & 0.698089 & -2.66178 & -2.96934 \\
\hline C & 4.001727 & -2.71699 & 0.332518 \\
\hline H & 3.63728 & 1.100048 & 1.112666 \\
\hline C & 4.673032 & -0.71822 & 1.560812 \\
\hline C & -0.20562 & -2.00937 & -3.79182 \\
\hline H & -1.12456 & -0.12389 & -4.34226 \\
\hline H & 0.908526 & -3.72167 & -3.06988 \\
\hline C & 4.807955 & -2.10007 & 1.275394 \\
\hline H & 4.089701 & -3.77363 & 0.101518 \\
\hline H & 5.311557 & -0.26187 & 2.310666 \\
\hline H & -0.72739 & -2.57103 & -4.56133 \\
\hline H & 5.553956 & -2.68626 & 1.804244 \\
\hline O & 2.293579 & -2.57587 & -1.26074 \\
\hline O & -2.29364 & -2.57585 & 1.260684 \\
\hline & & & \\
\hline
\end{tabular}


Optimized geometry of $\mathbf{3}-\mathrm{O}_{2}$ :

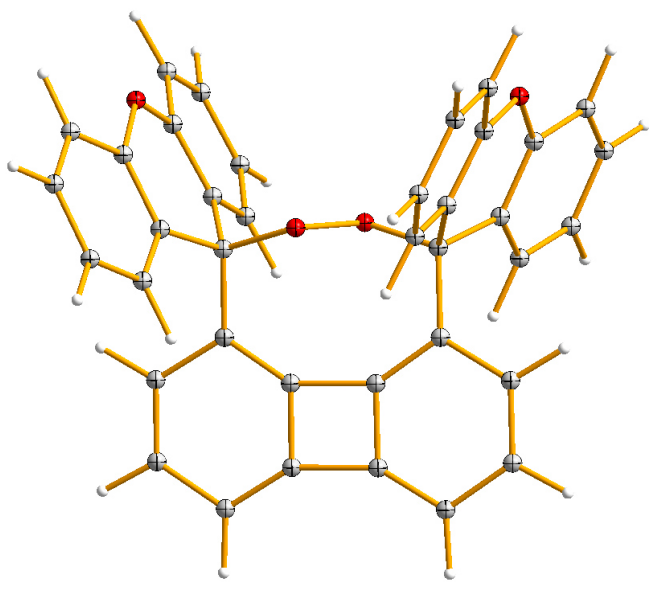

Cartesian coordinates of the optimized structure of 3$\mathrm{O}_{2}$ :

\begin{tabular}{|c|r|r|r|}
\hline Atom Type & \multicolumn{1}{|c|}{$\mathrm{X}$} & $\mathrm{Y}$ & $\mathrm{Z}$ \\
\hline $\mathrm{C}$ & 1.824217 & 4.456565 & -0.65719 \\
\hline C & 0.714437 & 3.752959 & -0.25697 \\
\hline C & 0.706992 & 2.328778 & -0.23059 \\
\hline C & 1.794333 & 1.548558 & -0.52169 \\
\hline C & 2.942324 & 2.274512 & -0.95606 \\
\hline C & 2.950595 & 3.664212 & -1.02632 \\
\hline H & 1.872496 & 5.541326 & -0.69451 \\
\hline H & 3.84332 & 1.727651 & -1.22266 \\
\hline H & 3.856908 & 4.164421 & -1.35824 \\
\hline C & -0.70677 & 2.328798 & 0.230306 \\
\hline C & -1.79418 & 1.548651 & 0.521404 \\
\hline C & -0.71416 & 3.752972 & 0.256815 \\
\hline C & -2.9421 & 2.27457 & 0.95588 \\
\hline C & -1.82391 & 4.45659 & 0.657141 \\
\hline C & -2.9503 & 3.664287 & 1.026251 \\
\hline H & -3.84313 & 1.727744 & 1.222439 \\
\hline H & -1.87208 & 5.541352 & 0.694631 \\
\hline H & -3.85659 & 4.16449 & 1.358233 \\
\hline C & 1.791176 & 0.039434 & -0.29951 \\
\hline C & 1.919713 & -0.75995 & -1.5852 \\
\hline C & 2.859514 & -0.38849 & 0.699108 \\
\hline C & 1.349218 & -0.33017 & -2.79288 \\
\hline C & 2.563586 & -2.0027 & -1.57487 \\
\hline C & 3.447362 & -1.65486 & 0.589978 \\
\hline C & 3.196368 & 0.400262 & 1.810579 \\
\hline C & 1.399435 & -1.11934 & -3.9389 \\
\hline H & 0.847633 & 0.631688 & -2.8204 \\
\hline C & 2.620373 & -2.81095 & -2.71466 \\
\hline & & & \\
\hline
\end{tabular}

\begin{tabular}{|r|r|r|r|}
\hline C & 4.34532 & -2.12815 & 1.552988 \\
\hline H & 2.742012 & 1.380748 & 1.914155 \\
\hline C & 4.088301 & -0.05628 & 2.777237 \\
\hline C & 2.031633 & -2.36853 & -3.89503 \\
\hline H & 0.941341 & -0.76842 & -4.85927 \\
\hline H & 3.133101 & -3.7662 & -2.65425 \\
\hline C & 4.660918 & -1.32846 & 2.646565 \\
\hline H & 4.780278 & -3.11431 & 1.421708 \\
\hline H & 4.332548 & 0.570792 & 3.630002 \\
\hline H & 2.073435 & -2.99329 & -4.78341 \\
\hline H & 5.35829 & -1.69446 & 3.39583 \\
\hline C & -1.79104 & 0.039524 & 0.299304 \\
\hline C & -1.9196 & -0.75967 & 1.585106 \\
\hline C & -2.85942 & -0.38844 & -0.69924 \\
\hline C & -1.34856 & -0.32997 & 2.792578 \\
\hline C & -2.56407 & -2.00212 & 1.575197 \\
\hline C & -3.44791 & -1.65446 & -0.58967 \\
\hline C & -3.19585 & 0.400079 & -1.81102 \\
\hline C & -1.39888 & -1.11888 & 3.938759 \\
\hline H & -0.84652 & 0.631663 & 2.819799 \\
\hline C & -2.62104 & -2.81008 & 2.715177 \\
\hline C & -4.34612 & -2.12764 & -1.55251 \\
\hline H & -2.74098 & 1.38029 & -1.91494 \\
\hline C & -4.088 & -0.05635 & -2.77752 \\
\hline C & -2.03178 & -2.36773 & 3.89531 \\
\hline H & -0.94033 & -0.76802 & 4.858928 \\
\hline H & -3.13431 & -3.76506 & 2.655101 \\
\hline C & -4.6613 & -1.32818 & -2.64638 \\
\hline H & -4.78158 & -3.11353 & -1.42088 \\
\hline H & -4.33189 & 0.570526 & -3.63053 \\
\hline H & -2.07374 & -2.99227 & 4.783838 \\
\hline H & -5.35886 & -1.69409 & -3.39526 \\
\hline O & -3.19387 & -2.49871 & 0.459047 \\
\hline O & 3.192959 & -2.4993 & -0.45849 \\
\hline O & -0.58826 & -0.35096 & -0.45018 \\
\hline & 0.588383 & -0.35093 & 0.450006 \\
\hline & & & \\
\hline
\end{tabular}


Optimized geometry of $[4]^{2+}$ :

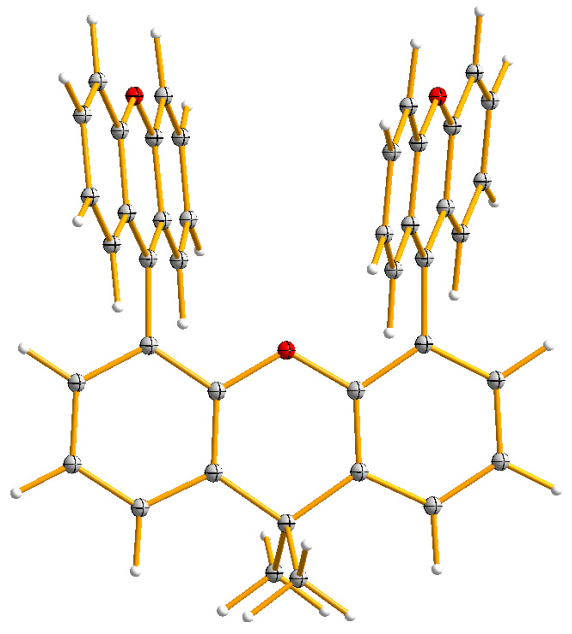

Cartesian coordinates of the optimized structure of $[4]^{2+}$ :

\begin{tabular}{|c|c|c|c|}
\hline Atom Type & $\mathrm{X}$ & $\mathrm{Y}$ & $\mathrm{Z}$ \\
\hline $\mathrm{C}$ & 3.223228 & -3.599962 & -0.853452 \\
\hline $\mathrm{C}$ & 3.979203 & -2.464108 & -0.575786 \\
\hline $\mathrm{C}$ & 3.387635 & -1.222176 & -0.294093 \\
\hline $\mathrm{C}$ & 1.990819 & -1.15497 & -0.310825 \\
\hline $\mathrm{C}$ & 1.198447 & -2.284694 & -0.615136 \\
\hline $\mathrm{C}$ & 1.834108 & -3.512554 & -0.86525 \\
\hline $\mathrm{C}$ & 1.991208 & 1.154356 & 0.310819 \\
\hline $\mathrm{C}$ & 3.388042 & 1.221097 & 0.294057 \\
\hline $\mathrm{C}$ & 3.980031 & 2.462823 & 0.57578 \\
\hline $\mathrm{H}$ & 5.062208 & 2.544551 & 0.573532 \\
\hline $\mathrm{C}$ & 3.224439 & 3.59891 & 0.853519 \\
\hline $\mathrm{C}$ & 1.835288 & 3.511959 & 0.865361 \\
\hline $\mathrm{C}$ & 1.199218 & 2.284328 & 0.615194 \\
\hline $\mathrm{H}$ & 3.712037 & -4.54512 & -1.067317 \\
\hline $\mathrm{H}$ & 5.061352 & -2.54619 & -0.573582 \\
\hline $\mathrm{H}$ & 1.234556 & -4.385235 & -1.107487 \\
\hline $\mathrm{H}$ & 3.713564 & 4.5439 & 1.067409 \\
\hline $\mathrm{H}$ & 1.236033 & 4.384832 & 1.107647 \\
\hline $\mathrm{C}$ & 4.262746 & -0.000676 & -0.000071 \\
\hline 0 & 1.296674 & -0.000194 & -0.000004 \\
\hline $\mathrm{C}$ & 5.158222 & 0.289568 & -1.235668 \\
\hline $\mathrm{H}$ & 5.800108 & -0.566724 & -1.46336 \\
\hline $\mathrm{H}$ & 4.553269 & 0.507423 & -2.122264 \\
\hline $\mathrm{H}$ & 5.813521 & 1.146235 & -1.051524 \\
\hline $\mathrm{C}$ & 5.158306 & -0.291176 & 1.235402 \\
\hline $\mathrm{H}$ & 4.553412 & -0.50883 & 2.122086 \\
\hline $\mathrm{H}$ & 5.81332 & -1.148044 & 1.051181 \\
\hline $\mathrm{H}$ & 5.800495 & 0.564917 & 1.462989 \\
\hline $\mathrm{C}$ & -0.276921 & -2.235314 & -0.751035 \\
\hline
\end{tabular}

\begin{tabular}{|c|c|c|c|}
\hline $\mathrm{C}$ & -1.10337 & -2.994612 & 0.122532 \\
\hline $\mathrm{C}$ & -0.890328 & -1.528936 & -1.824549 \\
\hline $\mathrm{C}$ & -0.61191 & -3.737082 & 1.239942 \\
\hline $\mathrm{C}$ & -2.510925 & -3.024538 & -0.109521 \\
\hline $\mathrm{C}$ & -2.303755 & -1.61156 & -1.984664 \\
\hline $\mathrm{C}$ & -0.164499 & -0.804348 & -2.816425 \\
\hline $\mathrm{C}$ & -1.470449 & -4.471142 & 2.027397 \\
\hline $\mathrm{H}$ & 0.449645 & -3.715683 & 1.45735 \\
\hline $\mathrm{C}$ & -3.385294 & -3.767507 & 0.689783 \\
\hline $\mathrm{C}$ & -2.974967 & -0.990215 & -3.04394 \\
\hline $\mathrm{H}$ & 0.916189 & -0.760834 & -2.746976 \\
\hline $\mathrm{C}$ & -0.820108 & -0.197314 & -3.863949 \\
\hline $\mathrm{C}$ & -2.858995 & -4.493105 & 1.746314 \\
\hline $\mathrm{H}$ & -1.085147 & -5.039416 & 2.868125 \\
\hline $\mathrm{H}$ & -4.445896 & -3.770625 & 0.460232 \\
\hline $\mathrm{C}$ & -2.229734 & -0.287416 & -3.975888 \\
\hline $\mathrm{H}$ & -4.051934 & -1.09501 & -3.126736 \\
\hline $\mathrm{H}$ & -0.255717 & 0.334812 & -4.623296 \\
\hline $\mathrm{H}$ & -3.522983 & -5.085682 & 2.369042 \\
\hline $\mathrm{H}$ & -2.732525 & 0.181645 & -4.816718 \\
\hline $\mathrm{C}$ & -0.276174 & 2.235419 & 0.751086 \\
\hline $\mathrm{C}$ & -1.102378 & 2.994871 & -0.122572 \\
\hline $\mathrm{C}$ & -0.88979 & 1.529337 & 1.824665 \\
\hline $\mathrm{C}$ & -0.61068 & 3.737113 & -1.240028 \\
\hline $\mathrm{C}$ & -2.50993 & 3.025216 & 0.109449 \\
\hline $\mathrm{C}$ & -2.303201 & 1.612368 & 1.98474 \\
\hline $\mathrm{C}$ & -0.164183 & 0.804636 & 2.816622 \\
\hline $\mathrm{C}$ & -1.468992 & 4.47136 & -2.027555 \\
\hline $\mathrm{H}$ & 0.450875 & 3.715397 & -1.457405 \\
\hline $\mathrm{C}$ & -3.384073 & 3.768364 & -0.689938 \\
\hline $\mathrm{C}$ & -2.97461 & 0.991303 & 3.044054 \\
\hline $\mathrm{H}$ & 0.916494 & 0.760807 & 2.747189 \\
\hline $\mathrm{C}$ & -0.819984 & 0.197883 & 3.864187 \\
\hline $\mathrm{C}$ & -2.85754 & 4.493731 & -1.746512 \\
\hline $\mathrm{H}$ & -1.083512 & 5.039469 & -2.868312 \\
\hline $\mathrm{H}$ & -4.444679 & 3.771802 & -0.460415 \\
\hline $\mathrm{C}$ & -2.229588 & 0.288388 & 3.976085 \\
\hline $\mathrm{H}$ & -4.05155 & 1.096393 & 3.126819 \\
\hline $\mathrm{H}$ & -0.255763 & -0.334335 & 4.623597 \\
\hline $\mathrm{H}$ & -3.521343 & 5.086451 & -2.369302 \\
\hline $\mathrm{H}$ & -2.732525 & -0.180462 & 4.816945 \\
\hline 0 & -3.061379 & 2.330532 & 1.127769 \\
\hline 0 & -3.062157 & -2.329612 & -1.127795 \\
\hline
\end{tabular}


Optimized geometry of $4-\mathrm{O}_{2}$ :

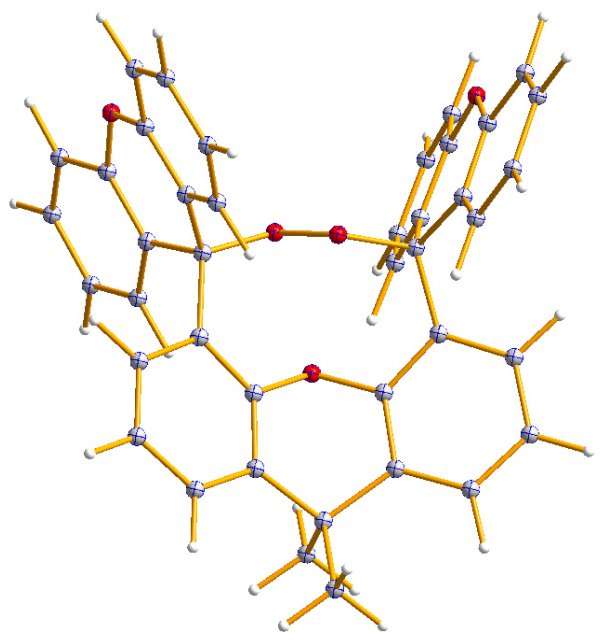

Cartesian coordinates of the optimized structure of 4$\mathrm{O}_{2}$ :

\begin{tabular}{|c|l|l|l|}
\hline Atom Type & \multicolumn{1}{|c|}{$\mathrm{X}$} & \multicolumn{1}{|c|}{$\mathrm{Y}$} & \multicolumn{1}{c|}{$\mathrm{Z}$} \\
\hline $\mathrm{C}$ & 2.11785 & -3.55484 & -1.95155 \\
\hline C & 0.978573 & -4.21652 & -1.47338 \\
\hline C & 0.126947 & -3.57929 & -0.56912 \\
\hline C & 0.470967 & -2.27542 & -0.17899 \\
\hline C & 1.550983 & -1.55305 & -0.68529 \\
\hline C & 2.394678 & -2.24188 & -1.57162 \\
\hline C & -1.68031 & -1.75901 & 0.41896 \\
\hline C & -2.19005 & -3.03115 & 0.138972 \\
\hline C & -3.57032 & -3.12831 & -0.05708 \\
\hline H & -4.03465 & -4.0864 & -0.27031 \\
\hline C & -4.37018 & -1.98046 & 0.022775 \\
\hline C & -3.79913 & -0.7173 & 0.194679 \\
\hline C & -2.41003 & -0.57325 & 0.341618 \\
\hline H & 2.783301 & -4.0636 & -2.6439 \\
\hline H & 0.769254 & -5.22597 & -1.8137 \\
\hline H & 3.26255 & -1.73546 & -1.98428 \\
\hline H & -5.44664 & -2.06753 & -0.09872 \\
\hline H & -4.43292 & 0.163795 & 0.169916 \\
\hline C & -1.15835 & -4.17453 & 0.049792 \\
\hline O & -0.34796 & -1.66338 & 0.74124 \\
\hline C & -0.83739 & -4.6877 & 1.48356 \\
\hline H & -0.08288 & -5.48218 & 1.440718 \\
\hline H & -0.4551 & -3.8845 & 2.119889 \\
\hline H & -1.74298 & -5.09306 & 1.950387 \\
\hline C & -1.69553 & -5.35177 & -0.78131 \\
\hline H & -1.93768 & -5.0499 & -1.8064 \\
\hline H & -0.96133 & -6.16305 & -0.82449 \\
\hline H & -2.59836 & -5.7683 & -0.32265 \\
\hline C & 1.846737 & -0.08657 & -0.3013 \\
\hline & & & \\
\hline
\end{tabular}

\begin{tabular}{|c|c|c|c|}
\hline $\mathrm{C}$ & 2.207762 & 0.756948 & -1.52008 \\
\hline $\mathrm{C}$ & 2.950722 & -0.00664 & 0.748538 \\
\hline $\mathrm{C}$ & 1.521905 & 0.637465 & -2.73964 \\
\hline $\mathrm{C}$ & 3.171697 & 1.766355 & -1.41777 \\
\hline $\mathrm{C}$ & 3.881914 & 1.037929 & 0.719022 \\
\hline $\mathrm{C}$ & 3.014531 & -0.91238 & 1.819579 \\
\hline $\mathrm{C}$ & 1.782611 & 1.490771 & -3.80808 \\
\hline $\mathrm{H}$ & 0.763822 & -0.13197 & -2.83848 \\
\hline $\mathrm{C}$ & 3.448128 & 2.633203 & -2.48103 \\
\hline $\mathrm{C}$ & 4.850017 & 1.182425 & 1.720093 \\
\hline $\mathrm{H}$ & 2.295428 & -1.72415 & 1.862361 \\
\hline $\mathrm{C}$ & 3.96934 & -0.78203 & 2.823264 \\
\hline $\mathrm{C}$ & 2.749286 & 2.495923 & -3.67523 \\
\hline $\mathrm{H}$ & 1.22984 & 1.380235 & -4.73678 \\
\hline $\mathrm{H}$ & 4.21029 & 3.395183 & -2.34838 \\
\hline $\mathrm{C}$ & 4.889156 & 0.274325 & 2.772002 \\
\hline $\mathrm{H}$ & 5.554512 & 2.005601 & 1.648978 \\
\hline $\mathrm{H}$ & 3.996514 & -1.49453 & 3.642874 \\
\hline $\mathrm{H}$ & 2.960205 & 3.168173 & -4.50283 \\
\hline $\mathrm{H}$ & 5.639793 & 0.385467 & 3.550155 \\
\hline $\mathrm{C}$ & -1.70115 & 0.801781 & 0.298227 \\
\hline $\mathrm{C}$ & -1.52404 & 1.424381 & 1.672515 \\
\hline $\mathrm{C}$ & -2.42775 & 1.758928 & -0.64228 \\
\hline $\mathrm{C}$ & -1.14212 & 0.664142 & 2.790876 \\
\hline $\mathrm{C}$ & -1.72045 & 2.797153 & 1.865477 \\
\hline $\mathrm{C}$ & -2.5425 & 3.117815 & -0.3303 \\
\hline $\mathrm{C}$ & -2.86404 & 1.34439 & -1.91314 \\
\hline $\mathrm{C}$ & -0.94792 & 1.249177 & 4.037906 \\
\hline $\mathrm{H}$ & -0.97293 & -0.39878 & 2.669023 \\
\hline $\mathrm{C}$ & -1.52986 & 3.402444 & 3.113067 \\
\hline $\mathrm{C}$ & -3.09821 & 4.033957 & -1.23188 \\
\hline $\mathrm{H}$ & -2.76253 & 0.299007 & -2.1864 \\
\hline $\mathrm{C}$ & -3.41029 & 2.242936 & -2.82455 \\
\hline $\mathrm{C}$ & -1.13855 & 2.627723 & 4.198115 \\
\hline $\mathrm{H}$ & -0.6423 & 0.635762 & 4.880827 \\
\hline $\mathrm{H}$ & -1.70041 & 4.470922 & 3.204089 \\
\hline $\mathrm{C}$ & -3.53027 & 3.595506 & -2.47804 \\
\hline $\mathrm{H}$ & -3.17446 & 5.075362 & -0.93413 \\
\hline $\mathrm{H}$ & -3.73697 & 1.894397 & -3.80029 \\
\hline $\mathrm{H}$ & -0.98845 & 3.094846 & 5.167937 \\
\hline $\mathrm{H}$ & -3.95914 & 4.306188 & -3.17966 \\
\hline 0 & -2.12778 & 3.642689 & 0.863851 \\
\hline 0 & 3.91881 & 1.970513 & -0.28269 \\
\hline 0 & 0.76674 & 0.575517 & 0.430244 \\
\hline 0 & -0.41582 & 0.693776 & -0.45266 \\
\hline
\end{tabular}




\section{References}

1. Valentino, M. R.; Boyd, M. K., Quenching behavior of singlet excited 9-arylxanthylium cations. J. Org. Chem. 1993, 58 (21), 5826-5831.

2. Suzuki, T.; Nishida, J.-i.; Ohkita, M.; Tsuji, T., Preparation, Structure, and Redox Reactions of Nine-Membered Cyclic Peroxides: A Novel Electrochromic System Undergoing Reversible Extrusion and Trapping of O2. Angewandte Chemie International Edition 2000, 39 (10), 1804-1806.

3. Wang, H.; Gabbaï, F. P., Synthesis, Structure, and Cyclic Voltammetry of 4,6Bis(dimesitylboryl)dibenzofuran: Isolation of 4,6-Dilithiobenzofuran and 4,5-Dilithio-9,9dimethylxanthene as tmeda Adducts. Organometallics 2005, 24 (12), 2898-2902.

4. Kilyanek, S. M.; Fang, X.; Jordan, R. F., Synthesis and reactivity of a tetragallium macrocycle. Organometallics 2009, 28 (1), 300-305.

5. Wang, Y.-H.; Pegis, M. L.; Mayer, J. M.; Stahl, S. S., Molecular Cobalt Catalysts for $\mathrm{O}_{2}$ Reduction: Low-Overpotential Production of $\mathrm{H} 2 \mathrm{O} 2$ and Comparison with Iron-Based Catalysts. J. Am. Chem. Soc. 2017, 139 (46), 16458-16461.

6. Mase, K.; Ohkubo, K.; Fukuzumi, S., Efficient Two-Electron Reduction of Dioxygen to Hydrogen Peroxide with One-Electron Reductants with a Small Overpotential Catalyzed by a Cobalt Chlorin Complex. Journal of the American Chemical Society 2013, 135 (7), 2800-2808.

7. Fukuzumi, S.; Kuroda, S.; Tanaka, T., Flavin analog-metal ion complexes acting as efficient photocatalysts in the oxidation of $p$-methylbenzyl alcohol by oxygen under irradiation with visible light. Journal of the American Chemical Society 1985, 107 (11), 3020-3027.

8. Mair, R. D.; Graupner, A. J., Determination of Organic Peroxides by lodine Liberation Procedures. Analytical Chemistry 1964, 36 (1), 194-204.

9. Achord, J. M.; Hussey, C. L., Determination of dissolved oxygen in nonaqueous electrochemical solvents. Analytical Chemistry 1980, 52 (3), 601-602.

10. Li, Q.; Batchelor-McAuley, C.; Lawrence, N. S.; Hartshorne, R. S.; Compton, R. G., Anomalous solubility of oxygen in acetonitrile/water mixture containing tetra-n-butylammonium perchlorate supporting electrolyte; the solubility and diffusion coefficient of oxygen in anhydrous acetonitrile and aqueous mixtures. J. Electroanal. Chem. 2013, 688, 328-335.

11. Pegis, M. L.; Roberts, J. A. S.; Wasylenko, D. J.; Mader, E. A.; Appel, A. M.; Mayer, J. M., Standard Reduction Potentials for Oxygen and Carbon Dioxide Couples in Acetonitrile and $\mathrm{N}, \mathrm{N}$ -

Dimethylformamide. Inorg. Chem. 2015, 54 (24), 11883-11888. 